Seyahat ve Otel İşletmeciliği Dergisi/

Journal of Travel and Hospitality Management

17(1), 2020, 32-52.

Gönderim Tarihi: 29.07.2019

Kabul Tarihi: 30.12.2019

DOI:10.24010/soid.598292

\title{
“Turizm ve Kadın” Olgusunun Bibliyometrik Yaklaşım ile İncelenmesi
}

\section{A Bibliometric Analysis of "Tourism and Women" Studies}

\author{
Dr. Öğr. Üyesi Ebru Z. BOYACıOĞLU \\ Trakya Üniversitesi \\ İktisadi ve İdari Bilimler Fakültesi \\ E-posta: ebruzboyacioglu@yahoo.com
}

Çilem ELMAS

Trakya Üniversitesi

Sosyal Bilimler Enstitüsü

E-posta: cilemelmas@gmail.com

\section{Öz}

Turizm; multidisipliner yönü ile pekçok alanda çalışma yapılmasına imkân sağlamaktadır. Özellikle "turizm ve kadın" olgularını birlikte inceleyen çalışmaların son yıllarda arttığı görülmektedir. Bu noktadan hareketle çalışma; ulusal turizm alanyazınında kadın konusunda yapılmış çalışmaları nitel araştırma yöntemlerinden bibliyometrik bir yaklaşım ile tespit etmeyi amaçlamaktadır. Çalışma kapsamında Dergipark Akademik, Google Akademik ve YÖK Ulusal Tez veri tabanlarında "turizm ve kadın" kelimelerinin birlikte ele alındığı keşifsel nitelikte bir araştırma gerçekleştirilmiştir. Araştırma bulgularına göre 1994 ile 2019 yılları arasında ulusal ölçekte yayınlanmış 85 esere ulaşılmıştır. Eserlerin 46 makale, 23 tez, 14 bildiri ve 2 kitaptan oluştuğu tespit edilmiştir. Bu konuda yapılan ilk çalışma 1994 yılında gerçekleştirilmiş olup, 2016 yılından itibaren hız kazandığı belirlenmiştir. Yapılan çalışmaların \%54,12'si makalelerden oluşmaktadır. Makalelerde yazarların daha çok kadın olduğu tespit edilmiştir. Makalelerin \% 56,52'sinde ağırıklı olarak yabancı kaynak kullanılarak atıf yapılmıştır. Yazar sayısı durumuna yönelik incelemede genelde birden fazla (çok) yazarlı çalışmaların yapıldığı sonucu elde edilmiştir. Çalışmanın "turizm ve kadın" olgularını birlikte inceleyen araştırmalar kapsamında alanyazına katkı sağlaması ve gelecek araştırmalar için bir kaynak niteliği taşıması hedeflenmiştir.

Anahtar Kelimeler: Turizm, Kadın, Bibliyometrik Araştırma.

\begin{abstract}
Tourism; with its multidisciplinary aspect, enables to work in many fields. Especially the studies examining "tourism and women" together have increased in recent years. The aim of this study is to determine the studies on women in national tourism literature via bibliometric approach. An exploratory research was determined which includes "tourism and women" keywords together in Dergipark Academic, Google Academic and YOK National Thesis Center databases. According to the findings, 85 studies published at national literatüre between 1994 and 2019. These 85 studies, consist of 46 articles, 23 thesis, 14 papers and 2 books were processed with bibliometric analysis. The first study on this subjec twas carried out in 1994 and since 2016 topic has gained momentum. 54,12\% of the studies are composed of articles. In these articles, the authors were mostly women, $56,52 \%$ of the articles were cited mainly by using foreign references. The number of authors was concluded that there were more than one (multi) authors. It is aimed to contribute to the literature and to serve as a resource for future research within the scope of the studies that examine "tourism and women" together.
\end{abstract}

Key Words: Tourism, Women, Bibliometric Research. 


\section{Giriş}

Kadınların ekonomideki varlığı, sürdürülebilir kalkınma açısından önemli bir unsurdur. Kadının her alanda aktif katılımının sağlanması ve karar almanın tüm kademelerine eşitlikçi toplumsal cinsiyet ana yaklaşımının yerleştirilmesi ile ülkelerin kalkınmışlık düzeyinin arttırıması mümkündür. Dünya iş yaşamında çalışma saatlerinin \% 66'sı kadınlar tarafından gerçekleştirildiği halde kadınlar dünya gelirinin \%10'una ve mülkiyetin \%1'ine sahiptirler(UNDP,2010). Bu durum istihdam edilen kadınlarda da cinsiyet eşitsizliklerine bağlı sorunların sürdüğünün göstergesidir.

Ekonomik ve sosyal alanlardaki gelişmeler ile mesleklerin cinsiyete göre ayrılması azalmakta ve kadınların çalıştıkları meslekler ve sektörler çeşitlenmektedir. Bunun yanı sıra kadınların eğitim seviyesinin yükselmesi işgücüne katılmalarını arttıran unsurlar arasındadır. Günümüzde 'emek-yoğun' yapısı nedeni ile hizmet sektörünün işgücü ve istihdamdaki payı giderek artmaktadır. Hizmet sektörü içerisinde yer alan turizm; sayısal olarak sürekli büyümekte, ekonomik, sosyal ve çevresel olumlu etkiler yaratarak toplumların gelişimlerine katkıda bulunmaktadır. Hızla gelişen turizm sektörü özellikle kadınlara yeni istihdam alanı oluşturmakta, esnek çalışma olanakları ile işgücüne aktif katılımlarında önemli rol oynayarak, kadınları ekonomik ve sosyal olarak güçlendirmektedir(Ghodsee, 2005). Turizm sektörü giderek gelişen ve birçok sektörden etkilenen bir alan olduğu için kadın istihdamı yaratma özelliğine sahiptir.

Gelişimini hızla sürdüren turizm sektörüne ilişkin çeşitli araştırma yöntemlerinin kullanıldığı çok sayıda çalışma bulunmaktadır. Yapılan araştırmalar sıklıkla; farklı değişkenler arasındaki ilişkileri ve etkileşimleri inceleyen ampirik çalışmalardan oluşmaktadır. Turizm alanyazınında hangi konuların, hangi yöntemlerle ele alındığı, hangi sıklıkla gerçekleştirildiğine ilişkin çok sayıda çalışma bulunmasına rağmen kadın konusunun ne yoğunlukta, hangi değişkenlerle çalışıldığına dair bir çalışmaya ulaşılamamıştır. Oysa ki bir alanın gelişimi için hangi kavramların ön plana çıktığının tespiti alanı değerlendirebilmek açısından önemlidir ve konunun genel görünümünü belirleyerek eğilimleri ortaya çıkarmak açısından gereklidir(Kozan vd., 2014:117).

Farklı bilgi ve beceri düzeyine sahip kadınlara istihdam olanakları sunması nedeni ile turizm sektörü emek-yoğun olduğu kadar kadın-yoğun olarak da nitelendirilmektedir (Akoğlan Kozak,1996:16; Cave ve Kılıç,2010:285). Çalışma özellikle "turizm ve kadın" olgusuna odaklanarak, bu konuda yapılan bilimsel yayınların tespitini amaçlamaktadır. Çalışmada ulusal turizm alanyazınında kadın konusunda yapılmış çalışmaların nitel araştırma yöntemlerinden bibliyometrik analiz yaklaşımı kullanılarak keşfedilmesi amaçlanmıştır.

Yazın taraması sonucu "turizm ve kadın" olgusunu hem ulusal hem de uluslararası boyutta farklı yöntemlerle inceleyen araştırmalar olmasına rağmen bibliyometrik açıdan inceleyen bir araştırmaya rastlanmaması ve turizmin "emek-yoğun" özelliğinin yanı sıra "kadın-yoğun" nitelik taşıması çalışma alanını seçme konusunda etkili olmuştur. Elde edilen bulguların "turizm ve kadın" konularında yapılan çalışmaların zaman içindeki gelişimini ortaya koyması, araştırmacılara yeni veri sağlaması ve konunun gelişim sürecini somutlaştırması açısından önemli olduğu düşünülmektedir.

\section{Kavramsal Çerçeve}

Turizm sektöründe kadınlar yoğun istihdam edilmekte ve çok farklı görevlerde yer almaktadırlar(Tajeddini vd., 2017: 56). Hizmet sektörü olması, kadınların bilgi ve becerisi ile örtüşen alanların turizmde bulunması, kısmi çalışma koşulları, mevsimlik 
yapısı, mekânsal yoğunlaşması gibi sebeplerle kadınların bu sektörde çoğunlukla yer aldığı görülmektedir (Şit, 2016: 106). Dünya Turizm Örgütü verilerine göre turizm sektöründe çalışanların \% 54'ü kadındır(UNWTO,2019:9). Türkiye'deki durum ise Tablo 1 'de belirtilmiştir.

Tablo 1: Turizm Sektörü Ana Hizmet Kategorilerilşgücü Miktarı, 2016

\begin{tabular}{|l|c|c|c|c|c|c|}
\hline \multirow{2}{*}{$\begin{array}{c}\text { Turizm Tesisi } \\
\text { Türü }\end{array}$} & \multicolumn{2}{|c|}{ Erkek } & \multicolumn{2}{c|}{ Kadın } & \multicolumn{2}{c|}{ Toplam } \\
\cline { 2 - 7 } & İşgücü & $\%$ & İşgücü & $\%$ & İşgücü & $\%$ \\
\hline Konaklama ve & 255.189 & 40,1 & 112.705 & 44,8 & 367.894 & 41,4 \\
\hline $\begin{array}{l}\text { Yiyecek } \\
\text { İçecek Hizmetleri }\end{array}$ & 381.577 & 59,9 & 139.108 & 55,2 & 520.685 & 58,6 \\
\hline Toplam & 636.766 & 100 & 251.813 & 100 & 888.579 & 100 \\
\hline
\end{tabular}

Kaynak: TOBB Turizm Sektör Meclisi Turizm Raporu, 2016

Tablo 1 verilerine göre turizm sektöründe istihdam edilen erkek işgücü sayısı $636.766(\% 58,6)$ iken kadın işgücü sayısının $251.813(\% 41,4)$ olduğu görülmektedir. TÜİK 2019 İşgücü İstatistiklerine göre erkeklerde işgücüne katılma oranı \%72,6, kadınlarda ise \%34,9 dur. Bu durum Türkiye'de toplam kadın işgücünün \% 30'lar düzeyi gerçeğinden hareketle turizmde \% 41,4 lük kadın işgücü oranının, diğer sektörlere göre yüksek olduğunun bir göstergesidir. Bu durum turizmin diğer sektörlerden farklılığını ve toplumsal cinsiyet eşitliğini sağlama açısından katkısını ortaya koymaktadır. Buna ilaveten kadınlar; turizm sektöründe ziyaretçi, girişimci veya çalışan olmaları nedeniyle yüksek katılım oranına sahiptir.

Şekil 1: Dünyada Turizm Sektöründe Çalışan Kadınların Yüzdesel Dağılımı (\%)

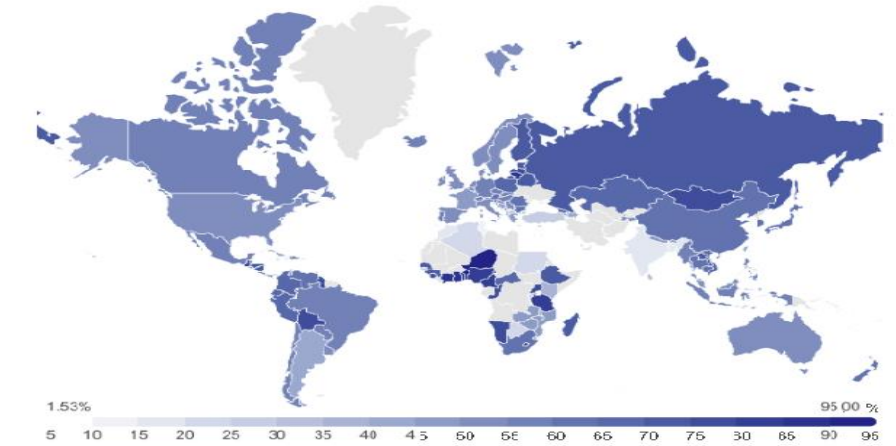

Kaynak: (UNWTO,2019:10). Gobal Report on Women and Tourism, Second Edition.

Şekil 1'de belirtilen Dünya Turizm Örgütü'nün Kadın ve Turizm Raporu'na göre ülkelerin çoğunluğunda kadınlar turizmde önemli bir rol oynamaktadır. Kadınlar turizmde işgücünün önemli bir kısmını temsil etmektedirler ancak genel olarak sektördeki alt düzey pozisyonlarda görev almaktadırlar. Kadınlar genellikle kendi turizm işletmelerinde girişimci olarak aktif rol alırken, üst yönetim pozisyonlarında yeterince temsil edilmemektedirler(UNWTO,2019:11). Turizm sektöründe yapılan çalışmalar kadınların gerek kentsel gerekse kırsal alanlarda girişimcilik faaliyetleri açısından güçlendiğini göstermektedir(El-Sharif vd.,2007;Koutsou vd.,2009;Arzjani ve Rahiminezhad,2011).

Kadınlar lehine yaşanan gelişmelere rağmen sektörde kadınların cinsel sömürü olarak kullanılması durumu yaygındır ve cinsiyetler arası ücret farkı da çok belirgindir(Women First, 2010). Turizmde cinsiyet ayrımcılığı yapıldığını gösteren çeşitli çalışmalar bulunmaktadır(Köse,2014:66; Dalkıranoğlu,2006:37). Cinsiyet ayrımcılığı; yatay ve dikey şekilde gerçekleşmektedir. Yatay ayrımcılık; kadın ve erkeğin aynı görev ve role sahip olması durumunda farklı görev ve sorumlukları alması durumudur. Dikey 
ayrımcılık ise; kadınlara daha az yetki ve sorumluluk, daha az görev verilerek terfi etmek için daha az fırsatı olması durumudur(Tükeltürk ve Perçin, 2008:114).

Demir (2011) tarafından turizm sektörüne yönelik yapılan araştırmada "Cinsiyet ve Medeni Durum" en önemli ayrımcılık olarak belirlenmiştir(Demir, 2011: 480). Arlı (2013) tarafından deniz turizm sektöründe yapılan araştırmada bireylerin cinsiyetinin; ayrımcılık ve önyargı konusundaki algılamaları etkilediği tespit edilmiştir.

Turizm sektörünün kendine özgü çalışma koşullarının olması da kadın işgücünü olumsuz etkilemektedir. Uzun çalışma saatleri, tatil günlerinde mesai gibi koşullar kadınların ev yaşamı ile iş hayatı arasında zorluklar yaşamasına neden olmaktadır (Ünlüönen ve Şahin, 2011:13). Kadınlar turizm sektöründe genellikle mevsimlik ya da yarı zamanlı ve düşük ücretlerle çalıştırılmakta ve küçük bir oranı yönetici pozisyonlarına yükselebilmektedir (Jordan, 1997: 528; Köse, 2014:65). Kadın; cinsiyeti nedeni ile düşük ücretle çalıştırıma, tehlikeli çalışma koşulları, cinsel taciz, fuhuş, kölelik ve insan ticareti gibi birçok farklı biçimde sömürü öğesi olarak kullanılabilmektedir(Jucan ve Jucan, 2013:440).

Kadın işgücüne yönelik cinsiyet temelli ayrımcılık ne kadar devam etse de, turizm sektörünün, kadınlar için halen önemli bir istihdam alanı yaratma durumu bilinmektedir(Cukier vd, 1996:252). Kadınların işgücüne katıımının artmasını sağlayan bir diğer neden de yarı zamanlı çalışma olarak görülmektedir. Kadınların turizm yoluyla güçlendirilmesi, yaşam koşullarında ve refah seviyelerinde artış etkisi olduğu kadar, kadınlara eşitlik sağlamak açısından da önemlidir.

Akademisyenler ve uluslararası kuruluşlar tarafından yapılan çalışmaların neredeyse tamamı, kadınların işlerinde, ücretlerinde, çalışma koşullarında, terfilerinde cinsiyetlerinden dolayı ayrımcılığa maruz kaldıklarını göstermektedir. Pek çok sektörde olduğu gibi, turizm sektöründe de halen kadınların cinsiyet ayrımcılığı, cam tavan engelleri, yönetim kademelerinde yetersiz temsil edilme, erkek meslektaşlarına göre daha az kazanma ve aile işletmelerinde ücretsiz çalıştırılma sorunları devam etmektedir. Turizmde de eşitsizliği gidermek için eğitim, araştırma ve politikalarda cinsiyet temelli eşitliği güçlendirmek gerekmektedir(Pritchard,2014:321). Kadınları olumsuz yönde etkileyen unsurların giderilerek, turizm sektöründe etkin yer almaları sürdürülebilir kalkınmanın sağlanabilmesinde önemli bir araçtır.

\section{Araştırma Yöntemi}

Bir bilim dalı ile ilgili üretilmiş farklı türlerden akademik yayınların ve alan yazının belirli zaman dilimleri ile incelenerek bilim dalının gelişme evresini ortaya koyması önemlidir(Temizkan vd, 2015). Bibliyometrik analiz bir disiplinde ya da bilim dalında yapılan araştırmaların profilini belirlemeyi hedefleyen ve bilimsel bilgi üretiminin gelişimi için faydalı veriler sunan son derece önemli bir araştırma türüdür (Hussain vd, 2011:2). Bibliyometrik analiz ile akademik bir alanda yayımlanmış çalışmaların çeşitli özellikleri (konu, yıl, anahtar kelime, yazar/yazarlar, atıf oranı, vb.) incelenerek bulgular elde edilmektedir. Bulgular söz konusu alanlarda ülke ve kurumlar arasındaki karşılaştırmalarda, bilimsel iletişim araçlarının kullanım oranlarının belirlenmesinde, alanyazında yapılan çalışmaların ve yazarların tespit edilmesinde ve dergilerin değerlendirilmesinde kullanılabilmektedir(Yalçın, 2010: 206).

Bibliyometri kavramı; ilk olarak Pritchard tarafından "matematiksel ve istatistiksel yöntemlerin bilimsel iletişim ortamlarına uygulanması" şeklinde tanımlanmıştır(Pritchard,1969:348). Farklı bir tanımda "Bibliyometri" kavramı, "basılı 
olarak yayınlanmış çalışmaların niceliklerine yönelik araştırmaları" ifade etmektedir (Broadus, 1987:376). Diodato (1994) ise bibliyometri kavramını, "yayımlanan dergi, kitap, vb. bilimsel araçların incelenmesinde kullanılan matematiksel ve istatistiksel yöntem" şeklinde tanımlamıştır(Diodato,1994:250).

Bibliyometrik araştırmaların yapıldığı disiplinlerden biri de turizmdir(Arıca ve Çorbacı,2019:265). Turizm alanyazınında gerek ulusal gerekse uluslararası çalışmaların bibliyometrik özelliklerinin belirlenmesine ilişkin pekçok araştırma bulunmaktadır. Turizm sektörünün sayısal olarak büyümesi ve araştırma yapan akademisyen sayısının artması bibliyometri yönteminin turizm alanındaki çalışmalarda tercih edilmesinde önemli bir neden olmaktadır(Şahin ve Acun, 2015). Turizm alanyazınında yapılan araştırmalarda bibliyometrik yaklaşım genellikle dergi ve makalelerin değerlendirmesinde kullanılmaktadır(Hall,2011:16). Dergilere yönelik yayınlanmış uluslararası çalışmaların bir kısmı Palmer vd., (2005); Ryan (2005); Singh vd., (2007); Cheng vd., (2011) tarafından gerçekleştirilmiştir. Bunlara ilaveten Bao (2002); yayınlanmış turizm tezlerini bibliyometrik açıdan incelemiştir.

Jogaratnam vd. (2005), 1992-2001 yılları arasında turizm alanındaki 11 dergiyi inceledikleri çalışmalarında makaleleri; yazarların üniversiteleri ve en fazla yayın yaptıkları dergiler açısında değerlendirmişlerdir. Ryan (2005), 1990-2004 yıllarında önemli turizm dergilerinde yayımlanmış makalelerin yazarlarını incelemiştir. Turizm alanında bir başka kapsamlı araştırmada McKercher (2006) 25 turizm dergisinde yayımlanan 3.153 makaleyi incelemiştir. Huang ve Hsu(2008) ise, 2000-2005 yılları arasında Çin'in Tourism Tribune dergisinde yayımlanmış 500 makaleyi incelemiştir.

Türkiye'de de bibliyometrik yöntem kullanılarak yapılan çeşitli çalışmalar bulunmaktadır. Dergilerin bibliyometrik incelenmesi ile ilgili yapılan ilk çalışma Kozak (1994) tarafından Anatolia Turizm Araştırmaları Dergisi'nin ilk beş yılında yayımlanan makalelerin ele alındığı araştırmadır. Kozak (1994), yazarların unvan ve kurumlarını, makalenin konusunu, yılını, sayfa ve yazar sayısını, araştırma yöntemini ve yazının çeviri olup olmadığını incelemiştir. Kozak (1995) benzer şekilde Türkiye'de turizm alanında yayımlanmış olan makaleleri konuları, yayınlandığı dergi, yayın yılı, yazarların unvanları ve makalelerin görgül veya kavramsal temelli olma durumu gibi farklı bibliyometrik özellikleri açısından incelemiştir.

Evren ve Kozak (2012) 2000-2010 yıllarında Türkiye'deki turizm dergilerinde yayımlanmış makaleleri bibliyometrik açıdan incelemişlerdir. Özel ve Kozak (2012) 2000-2011 yıllarında turizm pazarlaması alanında yayımlanmış makalelerin bibliyometrik profilini incelemiştir. Türktarhan ve Kozak (2012) 1985-1994 yıllarında yayımlanmış Turizm Yıllığı'nı değerlendirmiştir. Zencir ve Kozak (2012) Sosyal Bilimler Enstitüsü Dergileri'nde yayımlanmış turizm makalelerini, yazar, konu, yöntem vb. bibliyometrik özellikleri ile ele almıştır. Yüncü ve Kozak (2012) Anatolia Turizm Araştırmaları Dergisi'nde yayımlanmış makaleleri; konularını ve kurumlar arası işbirliğini sosyal ağ analizi ile incelemiştir. Çiçek ve Kozak (2012) Anatolia: Turizm Araştırmaları Dergisi'nde yayımlanmış makaleleri bibliyometrik özellikleri ile inceleyerek 3 dönemli karşılaştırma yapmıştır. Arıca, 2014; Aydın, 2017; Demirbulut ve Dinç, 2017; Şahin vd., 2018, hazırlanmış turizm tezlerini, Çakıcı, vd., 2013; Yılmaz, 2017 ise yayınlanmış kongre bildirilerini bibliyometrik özellikleri açısından incelemiştir.

Kozan vd. (2014) tarafından gerçekleştirilen araştırmada deniz turizminin olgusal gelişimini birincil ve ikincil gruplar olarak gruplandırarak 256 adet yayına ulaşmıştır. Bozok vd (2017) kırsal turizm konusunda ulusal ve uluslararası akademik çalışmaları bibliyometrik açıdan inceleyerek 400 den fazla akademik çalışmaya ulaşmıştır. Gül ve 
Gül (2018) yaptıkları çalışmada 2007-2017 yılları arasında kırsal kalkınma ve kırsal turizm alanındaki lisansüstü tezleri bibliyometrik özellikleri açısından belirlemiş,70 adet yüksek lisans ve 18 adet doktora tezi tespit etmiştir. Işık ve diğerlerinin (2019) yaptığı çalışmada "turizm ve girişimcilik" konularında 96 esere ulaşılmış, çalışmaların 2010 yılı itibari ile arttığı; girişimcilik özellikleri, kadın girişimciliği ve iç girişimcilik konularına ağırlık verildiği belirlenmiştir.

Bulgular; turizm disiplinini ulusal ve uluslararası alanyazında farklı çerçevelerden bibliyometrik açıdan inceleyen araştırmaların olduğunu göstermektedir. Turizmin hızla gelişmesi ve araştırmacı sayısının artması bibliyometri yönteminin turizm alanındaki çalışmalarda tercih edilmesinde önemli bir neden olmaktadır(Şahin ve Acun, 2015). Turizm alanyazınının gösterdiği değişimi ortaya koymak amacı ile bundan sonrada çeşitli bibliyometrik çalışmalar yapılmaya devam edecektir. Nitekim bu araştırma da bu alandaki örneklerden biridir.

\subsection{Araştırmanın Amacı}

Çalışmanın amacı "turizm ve kadın" olgusunu birlikte içeren çalışmaların ve kullanılan araştırma yöntemleri hakkındaki bilgilerin bibliyometrik analiz tekniği ile derlenerek verilmesidir. Çalışmada; Dergipark Akademik, Google Akademik ve YÖK Ulusal Tez veri tabanlarında ulaşılan, "turizm ve kadın" olgularının anahtar kelime olarak birlikte ele alındığı ve ulusal alanyazında yayınlanan makale, tez, bildiri ve kitaplar değerlendirmeye alınmıştır. Çalışmaların turizm alanını ve kadın konusunu kapsayıp kapsamadığını belirlemek amacı ile özet ve yöntem bölümleri ayrıca okunmuş ve değerlendirmeler bu kriterler dikkate alınarak gerçekleştirilmiştir.

Çalışma, 2019 yılının Nisan-Mayıs-Haziran aylarında çevrimiçi olarak taranabilen veri tabanlarında yayınlanan akademik kaynaklardan faydalanılarak oluşturulmuştur. Çalışmada Kozak'ın 2000 yılında yaptığı çalışma referans alınmış olup çalışma kapsamında "Turizm ve Kadın" olgusunun gelişmesinde etkili olan tezler, makaleler, bildiriler ve kitaplar incelemeye alınmıştır. Bibliyometrik profilin oluşturulması için elde edilen çalışmalar belirli parametreler doğrultusunda tablolar halinde sunulmuştur. Çalışmada bibliyometrik profilin ortaya çıkarılması için kullanılan parametreler:

- Çalışmanın Yayın Yılı, Yazarı/Yazarları

- Çalışmanın Amacı

- Çalışmanın Uygulama Alanı, Örneklem Grubu

- Çalışmanın Yöntemi

- Çalışmanın Bulguları/Sonucu olarak belirlenmiştir.

\subsection{Araştırma Bulguları}

"Turizm ve kadın" anahtar kelimeleri ile ulusal alanyazın tarandığında Türkiye'de 19942019 yılları arasında yayınlanmış 85 çalışmaya ulaşılmıştır. Elde edilen çalışmaların yıllara göre dağılımı Tablo 2'de gösterilmiştir.

Tablo 2: "Turizm ve Kadın” Konulu Çalışmaların Yıllara Göre Dağılımı

\begin{tabular}{|l|c|c|c|c|c|}
\hline YII & Çalışma Sayısı & YII & Çalışma SayıSI & YII & Çalışma Sayısı \\
\hline 1994 & 2 & $\mathbf{2 0 0 7}$ & 1 & $\mathbf{2 0 1 4}$ & 8 \\
\hline $\mathbf{1 9 9 6}$ & 1 & $\mathbf{2 0 0 8}$ & 5 & $\mathbf{2 0 1 5}$ & 3 \\
\hline 1997 & 3 & $\mathbf{2 0 0 9}$ & 3 & $\mathbf{2 0 1 6}$ & 9 \\
\hline $\mathbf{2 0 0 1}$ & 2 & $\mathbf{2 0 1 0}$ & 1 & $\mathbf{2 0 1 7}$ & 18 \\
\hline $\mathbf{2 0 0 2}$ & 1 & $\mathbf{2 0 1 1}$ & 4 & $\mathbf{2 0 1 8}$ & 11 \\
\hline $\mathbf{2 0 0 4}$ & 1 & $\mathbf{2 0 1 2}$ & 2 & $\mathbf{2 0 1 9}$ & 6 \\
\hline $\mathbf{2 0 0 6}$ & 1 & $\mathbf{2 0 1 3}$ & 3 & & \\
\hline \multicolumn{3}{|c|}{ TOPLAM } & \multicolumn{5}{|c|}{} \\
\hline
\end{tabular}


Tablo 2 verilerine göre Türkiye'de ulaşılan en eski çalışma 1994 yılında yayınlanmıştır. Kadın ve turizm konulu çalışmaların 1994 yılında başlamış olmasına rağmen 2000'li yılların başında sayısal olarak çok fazla araştırmaya rastlanılmamıştır. Eksik olan yıllarda çalışma verisi elde edilememiştir. 2016 yılından itibaren kadın ve turizm konusu ciddi bir ivme göstermiştir ve bu durum halen devam etmektedir. Son yıllarda araştırmalardaki artış konuya gösterilen ilgi ve önemin artması şeklinde değerlendirilebilir. Araştırmanın sınırlılıkları içinde ulaşılabilen çalışmalar incelenmiştir, ulaşılamamış çalışmaların da olabileceği dikkate alınmalıdır. Araştırma sonucu elde edilen bulgular makale, tez, kitap ve bildiri olarak dört ayrı başlık altında incelenmiştir.

Tablo 3: Birincil Kaynakların Dağılımı

\begin{tabular}{|l|c|c|}
\hline Yayınlar & Frekans & Yüzde \% \\
\hline Makale & 46 & $\% 54,12$ \\
\hline Tez & 23 & $\% 27,06$ \\
\hline Bildiri & 14 & $\% 16,47$ \\
\hline Kitap & 2 & $\% 2,35$ \\
\hline Toplam & $\mathbf{8 5}$ & $\% \mathbf{1 0 0}$ \\
\hline
\end{tabular}

Çevrimiçi ulaşılan kaynakların dağılımı Tablo 3'de belirtilmiştir. Ulusal alanyazında elde edilen araştırmaların çoğunluğunun $(\% 54,12)$ makale olduğu tespit edilmiştir. Bulgular "turizm ve kadın" konusunun daha çok makale düzeyinde ele alındığını göstermektedir.

\subsubsection{Makaleler}

Ulusal düzeyde yapılan araştırmalar neticesinde turizm ve kadın konusunun 1994 yılından itibaren araştırılmaya başlandığı saptanmıştır. Araştırma sonucunda 1994-2019 yılları arasında 46 adet makaleye ulaşıımıştır. Ulusal alanyazında yapılan ilk araştırmanın Akoğlan Kozak'a (1994) ait olduğu tespit edilmiştir. Ulaşılan 46 makalenin 24'ünde nicel, 15 'inde ise nitel araştırma yöntemleri kullanılmıştır. 6 makale ikincil kaynak kullanılarak yapılan literatür araştırması ve sadece bir makale ise Swot analizi ile gerçekleştirilmiştir. Makalelerin çoğunluğu veri toplama yöntemlerinden anket aracılığı ile yapılmıştır. Araştırma neticesinde elde edilen ulusal düzeyde yazıımış makalelerin \%56,52'sinde ağırlıklı olarak yabancı kaynaklar kullanılmıştır.

Tablo 4: Makale Yazarlarının Cinsiyetlerine Göre Dağılımı

\begin{tabular}{|l|l|l|l|l|l|}
\hline \multicolumn{2}{|l|}{ Tek Yazarlı Makaleler } & \multicolumn{3}{l|}{ Çok Yazarlı Makaleler } & \multicolumn{2}{l|}{ Karma Yazarı Makaleler } \\
\hline Kadın & 15 & Kadın & 10 & Kadın-Erkek Karma & 14 \\
\hline Erkek & 1 & Erkek & 6 & & \\
\hline Toplam & $\mathbf{1 6}$ & Toplam & $\mathbf{1 6}$ & Toplam & $\mathbf{1 4}$ \\
\hline
\end{tabular}

Tablo 4 verilerine göre bu konuda çalışma yapan yazarların kadın ağırlıklı olduğu tespit edilmiştir. Turizm alanyazınında kadın olgusunun yine kadınlar tarafından inceleniyor olması dikkat çekicidir. Makalelerin 16 tanesi $(\% 34,78)$ tek yazarlıdır, 30 tanesi $(\% 65,22)$ ise çoklu yazarlı çalışmalardır. Çoklu yazarlı çalışmaların 16 tanesi yine kadın yazarlar tarafından kaleme alınmıştır. Makalelere ilişkin araştırma alanı, amaç, yöntem ve sonuçlar Tablo 5'te gösterilmektedir. 
Tablo 5: "Turizm ve Kadın” Konuları Üzerine Yapılan Makaleler

\begin{tabular}{|c|c|c|c|c|}
\hline Yazar/YıI & Amaç & Araştırma Alanı & Yöntem & Sonuç \\
\hline $\begin{array}{l}\text { Başaran ve Ateş, } \\
\text { (2019) }\end{array}$ & $\begin{array}{l}\text { Kırsal kalkınma bölgelerinde kadın } \\
\text { istihdamının incelenmesi }\end{array}$ & $\begin{array}{c}\text { Gazlıgöl bölgesi termal } \\
\text { tesislerde çalışan } \\
\text { kadınlar }\end{array}$ & $\begin{array}{l}\text { Anket ve mülakat } \\
\text { yöntemi }\end{array}$ & $\begin{array}{c}\text { Kadınlar iş imkanının kısıtlı olmasından dolayı } \\
\text { ailelerine destek olmak için termal tesislerde } \\
\text { çalışmayı seçmişlerdir. }\end{array}$ \\
\hline $\begin{array}{l}\text { Kaya ve Topbaş, } \\
\text { (2019) }\end{array}$ & $\begin{array}{l}\text { Türkiye'de turizm sektöründe cinsiyete } \\
\text { dayalı ücret ayrımcılığının hangi boyutta } \\
\text { olduğunun tespiti }\end{array}$ & $\begin{array}{l}\text { TÜİK (Hane halk1 } \\
\text { işgücü anketi) verileri }\end{array}$ & $\begin{array}{l}\text { Oaxaca ve Cotton } \\
\text { modeli, EKK yöntemi }\end{array}$ & $\begin{array}{l}\text { Turizmde cinsiyete dayalı ücret ayrımcıllı̆ı } \\
\text { yapıldığı tespit edilmiștir. }\end{array}$ \\
\hline $\begin{array}{l}\text { Korkmaz, Özkök ve } \\
\text { Uluocak, (2019) }\end{array}$ & $\begin{array}{l}\text { Yerel halkın yalnız seyahat eden kadın } \\
\text { turistlere bakış açısının toplumsal cinsiyet } \\
\text { eșitliği ve değerler bağlamında incelenmesi }\end{array}$ & $\begin{array}{l}\text { Gökçeada'da yaşayan } \\
\text { yerel halk }\end{array}$ & $\begin{array}{c}\text { Anket, Açıklayıcı Faktör } \\
\text { Analizi ve Korelasyon } \\
\text { Analizi }\end{array}$ & $\begin{array}{l}\text { Bölge halkının toplumsal cinsiyet rollerine eşitlikçi } \\
\text { yaklaştıkları, tek başına gelen kadın turistlere } \\
\text { yönelik bakış açısının olumlu olduğu saptanmıştır. }\end{array}$ \\
\hline Serinikli, (2019) & $\begin{array}{l}\text { Kırsal alandaki kadın girişimcilerin } \\
\text { faaliyetleri ve kooperatifleşmeye karşı } \\
\text { tutumlarının ortaya konulması }\end{array}$ & $\begin{array}{c}\text { Edirne ilindeki } 21 \text { köyde } \\
\text { yaşayan kadınlar }\end{array}$ & Ki-kare testi, & $\begin{array}{l}\text { Kadınların kooperatif konusunda bilgili oldukları } \\
\text { ve kooperatifleşmeye olumlu baktıkları tespit } \\
\text { edilmiştir. }\end{array}$ \\
\hline Bayram, (2018) & $\begin{array}{c}\text { Kadın girişimcilerin mevcut durumu, } \\
\text { toplumsal cinsiyet perspektifinden analizi ve } \\
\text { bölge turizmine etkilerinin tespiti }\end{array}$ & \begin{tabular}{|c|} 
Sinop ilinde butik \\
işletmelerin kadın \\
yöneticileri ve sahipleri
\end{tabular} & $\begin{array}{c}\text { Nitel araştırma, Yarı } \\
\text { yapılandırılmış görüşme, } \\
\text { mülakat }\end{array}$ & $\begin{array}{l}\text { Bölgesel algı ve geleneksel inançlar engeli büyük } \\
\text { ölçüde giderilmiş, turizmin kadınlar için elverişli } \\
\text { bir sektör olduğu tespit edilmiştir. }\end{array}$ \\
\hline $\begin{array}{l}\text { Çelik ve Şahingöz, } \\
\text { (2018) }\end{array}$ & $\begin{array}{c}\text { Turizm işletmelerinde çalışan kadın aşçıların } \\
\text { yaşadığı sorunlar ve çözüm önerilerinin } \\
\text { tespiti }\end{array}$ & $\begin{array}{l}\text { Ankara'da Aşçılar } \\
\text { Federasyonuna üye } \\
\text { kadın aşçılar }\end{array}$ & Anket, $\mathrm{X} 2$ analizi & $\begin{array}{l}\text { Kadın aşçların işe alımda ayrımcllı yaşadığı ve } \\
\text { cinsiyetlerine göre iş bölümü yapıldığ1 } \\
\text { belirlenmiştir. }\end{array}$ \\
\hline $\begin{array}{l}\text { Demirel ve Perçin, } \\
\text { (2018) }\end{array}$ & $\begin{array}{l}\text { Otellerde çalışan orta ve üst düzey kadın } \\
\text { yöneticilerin kariyer engellerinin kariyer } \\
\text { geliştirme stratejileri üzerindeki etkisi }\end{array}$ & $\begin{array}{c}\text { Alanya'da } 4-5 \text { yıldızlı } \\
\text { otellerde çalışan kadın } \\
\text { yöneticiler }\end{array}$ & $\begin{array}{l}\text { Anket, korelasyon ve } \\
\text { çoklu regresyon analiz }\end{array}$ & $\begin{array}{c}\text { Kadınların kariyer engellerinin kariyer stratejilerini } \\
\text { olumsuz etkilediği saptanmıştır. }\end{array}$ \\
\hline $\begin{array}{c}\text { Güçer, Keleş, } \\
\text { Demirdağ ve } \\
\text { Çelikkanat, (2018) } \\
\end{array}$ & $\begin{array}{c}\text { Kadın işgörenlerin karşılaştıkları sorunlar ve } \\
\text { bu sorunların örgütsel sessizlikleri üzerindeki } \\
\text { etkisinin belirlenmesi }\end{array}$ & $\begin{array}{c}\begin{array}{c}\text { Bodrum'daki 3-4-5 } \\
\text { yıldızlı otellerde çalışan } \\
\text { kadınlar }\end{array} \\
\end{array}$ & $\begin{array}{l}\text { ANOVA, } \\
\text { Korelasyon analizi }\end{array}$ & $\begin{array}{l}\text { Kadın çalışanların ücretlerinin düşüklüğg̈ ruh } \\
\text { hallerini olumsuz etkilemektedir, bu durum } \\
\text { örgütsel sessizlik düzeylerinde etkilidir. }\end{array}$ \\
\hline Ertaş, (2018) & $\begin{array}{l}\text { Otel çalışanlarının kadınların çalışmasına } \\
\text { karşı tutumunun incelenmesi. }\end{array}$ & \begin{tabular}{|c|} 
Türkiye'deki 4 ve 5 \\
yıldızlı otellerde çalışan \\
erkekler
\end{tabular} & $\begin{array}{l}\text { Anket, korelasyon ve } \\
\text { regresyon analizi }\end{array}$ & $\begin{array}{c}\text { Erkek Katılımcıların eğitim düzeylerinin yüksek } \\
\text { olması, kadınların çalışsmasına olumlu } \\
\text { yaklaştıklarını ortaya koymuştur. }\end{array}$ \\
\hline $\begin{array}{l}\text { Öktem, Kubat ve } \\
\text { Kizltan, (2018) }\end{array}$ & $\begin{array}{l}\text { Otel işletmelerinde çalışan kadınların } \\
\text { örgütsel adalet, işe yabancılaşma ve cam } \\
\text { tavan sendromu algıları incelenmesi }\end{array}$ & $\begin{array}{c}\text { Antalya, İstanbul, } \\
\text { Karahayıt, Pamukkale, } \\
\text { Denizli otellerinde } 11 \\
\text { kadın turizm uzmanı } \\
\end{array}$ & $\begin{array}{c}\text { Yüz yüze görüşme } \\
\text { tekniği Analitik hiyerarşi } \\
\text { süreci, }\end{array}$ & $\begin{array}{c}\text { Otel işletmelerinde yoğun iş temposu nedeniyle } \\
\text { kadınlarda en önemli algını işe yabancılaşma } \\
\text { olması görülmüştür. }\end{array}$ \\
\hline $\begin{array}{c}\text { Ayaz ve Çobanoğlu, } \\
\text { (2017) }\end{array}$ & $\begin{array}{c}\begin{array}{c}\text { Ev hanımlarının turistler için yöresel yemek } \\
\text { üretme konusundaki bakış açılarının ortaya } \\
\text { çkarılması. }\end{array} \\
\end{array}$ & $\begin{array}{c}\text { Bartın ilinde ikamet eden } \\
420 \text { ev kadını }\end{array}$ & $\begin{array}{l}\text { Anket, Faktör analizi, } \\
\text { ANOVA }\end{array}$ & $\begin{array}{l}\text { Ev kadınlarının yöresel yemek üretiminde } \\
\text { potansiyel bir kaynak olduğu saptanmıştır. }\end{array}$ \\
\hline $\begin{array}{l}\text { Çakır, Barakazı ve } \\
\text { Barakazı, (2017) }\end{array}$ & $\begin{array}{c}\text { Turizm işletmelerinde kadın istihdamının } \\
\text { önündeki engelleri ortaya koyarak kadınların } \\
\text { cinsiyet ayrımcılığı düşüncelerinin } \\
\text { belirlenmesi. }\end{array}$ & $\begin{array}{l}\text { Şanlıurfa'da turizm } \\
\text { işletmelerinde görev } \\
\text { yapan kadınlar }\end{array}$ & $\begin{array}{c}\text { Basit tesadüfi örnekleme } \\
\text { yöntemi, Anket }\end{array}$ & $\begin{array}{l}\text { Kadın ve erkek arasındaki görev dağılımı farkı } \\
\text { kadınları olumsuz etkilemekte ve iş } \\
\text { memnuniyetinde kararsızlık getirmektedir. }\end{array}$ \\
\hline $\begin{array}{l}\text { Çiçek, Zencirve } \\
\text { Kozak, (2017) }\end{array}$ & $\begin{array}{l}\text { Kadınların Türk turizm tarihinde ne tür } \\
\text { başarılar kazandıklarının tespiti }\end{array}$ & $\begin{array}{c}\text { Turizm sektöründe } \\
\text { çalışanlar }\end{array}$ & $\begin{array}{c}\text { Yüz yüze görüşme Sözlü } \\
\text { Tarih Yöntemi, }\end{array}$ & $\begin{array}{l}\text { Çalışan kadınların ekonomik, sosyal ve bireysel } \\
\text { olarak güçlendikleri tespit edilmiştir. }\end{array}$ \\
\hline Çoşar, (2017) & \begin{tabular}{|c|}
$\begin{array}{c}\text { Somut olmayan kültürel mirasın } \\
\text { korunmasında kadın emeği konulu } \\
\text { tamamlanmıs ve halen yürürlükteki projelerin } \\
\text { etkilerinin değerlendirilmesi }\end{array}$ \\
\end{tabular} & $\begin{array}{l}\text { Seferihisar'daki } \\
\text { projelerde yönetici } \\
\text { kadınlar }\end{array}$ & $\begin{array}{l}\text { Yüz yüze görüşme } \\
\text { tekniği, İçerik analizi }\end{array}$ & $\begin{array}{c}\begin{array}{c}\text { Geleneksel mutfağın geliştirilmesiyle kadınların el } \\
\text { emekleriyle ekonomik kazanç elde etmeleri } \\
\text { sağlanmıştır. }\end{array} \\
\end{array}$ \\
\hline $\begin{array}{l}\text { Diker, Taşpınar ve } \\
\text { Soylu, (2017) }\end{array}$ & \begin{tabular}{|c|} 
Kadına karşı olumsuz tutumlar ile çelişik \\
duygulu cinsiyetçilik iliş̧isinin araştırılması
\end{tabular} & $\begin{array}{l}\text { Taksim bölgesindeki 4-5 } \\
\text { yıldızlı otellerin mutfak } \\
\text { personelleri }\end{array}$ & $\begin{array}{l}\text { Anket, T-testi, ANOVA, } \\
\text { Regresyon ve korelasyon } \\
\text { analizi }\end{array}$ & $\begin{array}{c}\text { Araştırma sonucunda kadına yönelik olumsuz } \\
\text { tutum ile kararsız cinsiyetçilik arasında anlamlı } \\
\text { pozitif bir ilişki tespit edilmiştir }\end{array}$ \\
\hline $\begin{array}{l}\text { Işık, Çetinkaya ve Işık } \\
\text {,(2017) }\end{array}$ & $\begin{array}{c}\text { Konaklama işletmelerindeki kadın } \\
\text { çalışanların mutluluk düzeylerinin tespiti ve } \\
\text { mutluluğun iş tatmini üzerindeki etkisi }\end{array}$ & \begin{tabular}{|c|} 
Palandöken Turizm \\
merkezinde konaklama \\
işletmelerindeki kadınlar \\
\end{tabular} & $\begin{array}{l}\text { Anket, Korelasyon ve } \\
\text { Regresyon analizler }\end{array}$ & $\begin{array}{l}\text { Kadın çalışanların büyük çoğunluğun işlerinden } \\
\text { mutlu oldukları ve iş tatminlerinin arttığ1 } \\
\text { saptanmıştı. }\end{array}$ \\
\hline Kaya, (2017) & $\begin{array}{c}\text { Turizmde kadın istihdamı ve kadın } \\
\text { emeğinin merkezi konumunu } \\
\text { aydınlatılması }\end{array}$ & $\begin{array}{l}\text { Küresel ve yerel } \\
\text { bağlamda turizmde } \\
\text { istihdam edilen } \\
\text { kadınlar }\end{array}$ & $\begin{array}{l}\text { Literatür taraması } \\
\text { İkincil kaynak }\end{array}$ & $\begin{array}{c}\text { Turizm sektörünün modernite ile olan } \\
\text { bağından dolayı her geçen gün kadın } \\
\text { istihdamı artmaktadır. }\end{array}$ \\
\hline $\begin{array}{l}\text { Kayabaşı Torun, } \\
(2017)\end{array}$ & $\begin{array}{l}\text { Kırsaldaki kadınların turizm üzerindeki } \\
\text { etkisi ve rollerin incelenmesi }\end{array}$ & $\begin{array}{c}\text { Kırsal kesimde } \\
\text { yaşayan kadınlar }\end{array}$ & $\begin{array}{l}\text { Literatür taraması, } \\
\text { ikincil kaynak }\end{array}$ & $\begin{array}{l}\text { Kadınların sosyo-ekonomik durumlarının } \\
\text { iyileşmesi aile içi rolleri yükselmektedir. }\end{array}$ \\
\hline $\begin{array}{l}\text { Sökmen ve Şahingöz, } \\
\text { (2017) }\end{array}$ & \begin{tabular}{|} 
Konaklama sektöründeki kadınların cam \\
tavan sendromu ve zihinsel durağanlı̆̆ \\
Etkileyen değişkenlerden kurum ikliminin, iş \\
tatmini ile işten ayrılma niyetinin belirlemesi
\end{tabular} & $\begin{array}{l}\text { Antalya'da zincir otel } \\
\text { grubunun üç ayrı } \\
\text { işletmesinde yiyecek- } \\
\text { içecek departmanında } \\
\text { kadrolu kadınlar }\end{array}$ & $\begin{array}{c}\text { Anket, T-testi, } \\
\text { Regresyon ve korelasyon } \\
\text { analizi }\end{array}$ & $\begin{array}{l}\text { Kurumsal yapının kadın çalışanların iş tatmini } \\
\text { üzerinde anlamlı ve negatif, işten ayrılma niyetine } \\
\text { ise anlamlı ve pozitif etkisinin olduğu saptanmıştır. }\end{array}$ \\
\hline $\begin{array}{l}\text { Şimşek, Özgener ve } \\
\text { İlhan, (2017) }\end{array}$ & \begin{tabular}{|c|}
$\begin{array}{c}\text { Otantik liderliğin sosyal tembellik üzerindeki } \\
\text { etkilerinin ve bu iki değişken arasındaki } \\
\text { ilişkide yaşam tatminin düzenleyici rolü olup } \\
\text { olmadığının analizi }\end{array}$ \\
\end{tabular} & \begin{tabular}{|c|} 
Nevşehir'de turizm \\
sektöründe çalışan kadın \\
girişimciler ve \\
yöneticiler \\
\end{tabular} & \begin{tabular}{|c|} 
Anket, Kolmogorov- \\
Smirnov testi, Faktör \\
analizi, Pearson ve çoklu \\
regresyon analizi \\
\end{tabular} & $\begin{array}{l}\text { Çalışma sonucunda turizm sektöründeki kadın } \\
\text { girişimci ve yöneticiler arasında sosyal tembellik } \\
\text { eğiliminin orta düzeyde olduğu saptanmıştır. }\end{array}$ \\
\hline $\begin{array}{l}\text { Altındal ve Gül, } \\
\text { (2016) }\end{array}$ & $\begin{array}{c}\text { Güney Ege ve Batı Akdeniz bölgesindeki } \\
\text { kadın girişimcilerin risk alma deneyimlerinin } \\
\text { toplumsal cinsiyet temelli perspektif } \\
\text { bağlamında incelenmesi }\end{array}$ & \begin{tabular}{|c|} 
Bodrum-Marmaris, Kaş \\
Alanya yiyecek içecek, \\
konaklama sektöründeki \\
kadın girişimciler \\
\end{tabular} & $\begin{array}{c}\text { Nitel araştırma, } \\
\text { Derinlemesine görüşme, }\end{array}$ & $\begin{array}{c}\text { Turizmin mevsimsel, emek yoğun ve mikro ölçekli } \\
\text { aile işletmesi olması kadınlara yönelik olumsuz } \\
\text { bakış açısı getirmektedir. Mali riskler kadınları iş } \\
\text { hayatında sınırlandırmaktadır. } \\
\end{array}$ \\
\hline Ciğer ve Uyar, (2016) & $\begin{array}{c}\text { Konaklama işletmelerindeki kadın } \\
\text { muhasebecilerin kariyer süreçlerine etki eden, } \\
\text { cam tavanı oluşturan faktörlerin tespiti }\end{array}$ & $\begin{array}{c}5 \text { yıldızlı otellerin } \\
\text { muhasebe bölümünde } \\
\text { çalışan kadınlar ve } \\
\text { erkekler }\end{array}$ & Anket, T-testi, ANOVA & $\begin{array}{l}\text { Kadın çalışanlar kariyerleri için fedakârlık } \\
\text { yapmaktadır. Muhasebe mesleğini seçenler } \\
\text { eşlerinden destek görmektedirler. }\end{array}$ \\
\hline $\begin{array}{l}\text { Dinçer, Akova, } \\
\text { Ertuğral ve Çifçi, } \\
\text { (2016) }\end{array}$ & $\begin{array}{c}\text { Türkiye'de Kadın çalışanların turizm } \\
\text { sektöründe istihdam olanakları ve kadın } \\
\text { istihdamında karşışşlan engeller } \\
\text { incelenmiştir. }\end{array}$ & $\begin{array}{c}\text { Kadın çalışanların turizm } \\
\text { sektöründe karşılaştığ1 } \\
\text { engeller, Türkiye'deki } \\
\text { turizm sektörü }\end{array}$ & Swot analizi, & $\begin{array}{c}\text { Ayrımcılık, toplumsal ve mesleki olumsuz bakış } \\
\text { açısı, psikolojik ve fiziksel şiddet, çalşma şartları, } \\
\text { yasal düzenleme eksiklikleri turizmde kadın } \\
\text { istihdamını engelleyen faktörlerdir }\end{array}$ \\
\hline $\begin{array}{l}\text { Işık, Trrak ve Işık, } \\
\text { (2016) }\end{array}$ & $\begin{array}{c}\text { Turizm eğitimi alan kız öğrencilerin } \\
\text { girişimcilik ve inovasyon eğilimlerinin } \\
\text { belirlenmesi }\end{array}$ & $\begin{array}{c}\begin{array}{c}\text { Atatürk Üniversitesinde, } \\
\text { turizm eğitimi alan k1z } \\
\text { ögrenciler }\end{array} \\
\end{array}$ & Anket, T-testi, ANOVA & $\begin{array}{c}\begin{array}{c}\text { Potansiyel girişimci kadın adayların deneyime açık } \\
\text { ve kendilerine güveni yüksek bireyler olduğu } \\
\text { belirlenmiştir. }\end{array} \\
\end{array}$ \\
\hline
\end{tabular}


Tablo 5'in devamı

\begin{tabular}{|c|c|c|c|c|}
\hline $\begin{array}{l}\text { Karakaş ve Gökmen, } \\
\text { (2016) }\end{array}$ & $\begin{array}{c}\text { Amasra ve Safranbolu turizm kentlerindeki } \\
\text { kadın girişimcilerinin profilinin belirlenmesi }\end{array}$ & $\begin{array}{c}\text { Amasra ve } \\
\text { Safranbolu'daki kadın } \\
\text { turizm girișimcileri }\end{array}$ & \begin{tabular}{|c|} 
Anket, Mann Whitney \\
U, testi,Kruskal Wallis H \\
testi
\end{tabular} & $\begin{array}{c}\begin{array}{c}\text { Sosyal ve kültürel açıdan gelişmek isteyen kadınlar } \\
\text { ekonomik bağımsılılk içim girişimcilik } \\
\text { faaliyetlerine atılmışlardır }\end{array} \\
\end{array}$ \\
\hline $\begin{array}{l}\text { Pelit, Güçer ve } \\
\text { Demirdağ, (2016) }\end{array}$ & $\begin{array}{l}\text { Kadınların karşılaştığı sorunların analiz } \\
\text { edilmesi ve bu sorunların iş bırakma } \\
\text { eğilimlerine olan etkisinin belirlenmesi }\end{array}$ & \begin{tabular}{|c|} 
Afyonkarahisar, Ankara, \\
Çankırı, Gaziantep, Uş̧ak \\
Muğla, Kırşehir'deki \\
otellerdekadın işgörenler
\end{tabular} & $\begin{array}{c}\text { Anket, ANOVA, } \\
\text { korelasyon ve regresyon } \\
\text { analizi }\end{array}$ & $\begin{array}{c}\text { Kadın çalışanların yaşadığı sorunlar ile iş bırakma } \\
\text { eğilimleri arasında anlamlı ve pozitif bir iliş̧ki } \\
\text { olduğu saptanmıştır. }\end{array}$ \\
\hline $\begin{array}{l}\text { Uğuz ve Topbaş, } \\
\text { (2016) }\end{array}$ & $\begin{array}{c}\text { Turizm sektöründe kadın emeğine karşı } \\
\text { ayrımcı tutumun irdelenmesi ve ayrımcılığın } \\
\text { en sık görünüş biçimi olan ücret ayrımcıllığı } \\
\text { derecesinin tespit edilmesi }\end{array}$ & $\begin{array}{c}\text { TUİK e göre } 60.297 \\
\text { erkek ve } 16.804 \text { kadın } \\
\text { ve konaklama } \\
\text { işletmelerinde } 837 \text { erkek } \\
\text { ve } 281 \text { kadın çalışan }\end{array}$ & $\begin{array}{l}\text { Beşeri sermaye teorisi } \\
\text { Oaxaca ve Cotton } \\
\text { ayrışım yöntemleri }\end{array}$ & $\begin{array}{l}\text { Turizm sektöründe cinsiyet temelli ayrımcılı̆̆ın } \\
\text { genelden özele inildikçe arttı̆̆ ve } \\
\text { ücret farkının yaklaşık \%6'sının } \\
\text { ayrımcılıktan kaynaklandığı tespit edilmiştir }\end{array}$ \\
\hline Boyacıŏlu, (2014) & \begin{tabular}{|c|} 
Edirne'de kırsal turizm odaklı kadın \\
girişimciliğinin durumunun ortaya konulması
\end{tabular} & $\begin{array}{l}\text { Edirne'de faaliyetteki } \\
\text { kadın girişimciler }\end{array}$ & Nitel araştırma, Anket, & $\begin{array}{l}\text { Kadın girişimcilerin bölgenin kırsal turizm } \\
\text { potansiyeline katkılarının yüksek olduğu, } \\
\text { girişimcilik ile kadının konumunda olumlu } \\
\text { gelişmeler yaşandığı belirlenmiştir. }\end{array}$ \\
\hline $\begin{array}{l}\text { Uğuz ve Topbaş, } \\
\text { (2014) }\end{array}$ & $\begin{array}{c}\text { Türkiye'de kadın emeğinin uluslararası } \\
\text { verilerle kıyaslanması, Turizm sektörünün } \\
\text { istihdamda cinsiyetçi yapı itibariyle ele } \\
\text { alınarak yaşanılan sorunların tespiti }\end{array}$ & \begin{tabular}{|c|} 
Dünya Ekonomik \\
Forumu,, Sosyal İzleme \\
Örgütü ve BM Kalkınma \\
Programı endeksleri \\
\end{tabular} & $\begin{array}{c}\text { Literatür taraması Íkincil } \\
\text { kaynak }\end{array}$ & $\begin{array}{c}\text { Dünya geneli toplumsal cinsiyet bağlamında kadın } \\
\text { işgücünün özellikle ücret ve terfi konularında } \\
\text { ayrımcıllı̆a maruz kaldığı saptanmıştır. }\end{array}$ \\
\hline $\begin{array}{l}\text { Ülkü ve Köroğlu, } \\
\text { (2014) }\end{array}$ & $\begin{array}{l}\text { Kadın tüketicilerin turistik ürün satın alma } \\
\text { davranışlarını etkileyen faktörlerin } \\
\text { belirlenmesi }\end{array}$ & \begin{tabular}{|} 
İstanbul çıkıșlı paket \\
turları satın almış kadın \\
tüketiciler
\end{tabular} & $\begin{array}{l}\text { Anket, Tek yönlü } \\
\text { varyans analizi }\end{array}$ & $\begin{array}{l}\text { Kadın tüketicilerin medeni hal ve çocuk sahibi } \\
\text { olma durumlarının ürün satın alırken etkili olduğu } \\
\text { saptanmıştır. }\end{array}$ \\
\hline $\begin{array}{l}\text { Yirik ve Yildırım, } \\
\text { (2014) }\end{array}$ & $\begin{array}{c}\text { Turizm sektöründeki kadın girişimcilerin } \\
\text { bireysel değerlerinin demografik özellikleri } \\
\text { açısından incelemesi }\end{array}$ & \begin{tabular}{|c|} 
Antalya'da turizm \\
sektöründe çalışan kadın \\
girişimciler
\end{tabular} & \begin{tabular}{|c|} 
Anket, Frekans analizi, \\
Kruskal-Wallis ve \\
Mann-Whitney U testleri
\end{tabular} & $\begin{array}{l}\text { Kadın girişimcilerin eğitim düzeyleri ve yaşlarına } \\
\text { göre sektördeki başarıları değişim göstermektedir. }\end{array}$ \\
\hline $\begin{array}{l}\text { Yirik ve Yildırım, } \\
\text { (2014) }\end{array}$ & $\begin{array}{l}\text { Turizm sektöründeki kadın girişimcilerin } \\
\text { bireysel değerleri ile risk ve belirsizlik } \\
\text { algıları arasındaki ilişsinin incelenmesi }\end{array}$ & $\begin{array}{c}\text { Antalya'da turizm } \\
\text { sektöründe çalışan kadın } \\
\text { girişimciler }\end{array}$ & $\begin{array}{l}\text { Anket, Regresyon ve } \\
\text { korelasyon analizi }\end{array}$ & $\begin{array}{l}\text { Kadın girişimciliğinin eğitim ile doğru orantılı } \\
\text { ilerlediği,güç faktörünün risk ve belirsizlik algısı } \\
\text { üzerine algısının yüksek olduğu saptanmıştır. }\end{array}$ \\
\hline Fidan ve Nam, (2012) & $\begin{array}{l}\text { Kırsal turizmde kadınların yerini ve } \\
\text { etkinliğini ortaya konulması }\end{array}$ & $\begin{array}{c}\text { Taraklı'da faaliyet } \\
\text { gösteren kadın } \\
\text { girişimciler }\end{array}$ & $\begin{array}{c}\text { Yüz yüze görüşme, } \\
\text { derinlemesine mülakat, } \\
\text { gözlem }\end{array}$ & $\begin{array}{l}\text { Kadınların kırsal turizm gelişmesine katkısı göz } \\
\text { ardı edilemeyecek kadar yüksektir. }\end{array}$ \\
\hline Uçar, (2012) & $\begin{array}{l}\text { Antropoloji bakış açısıyla } \\
\text { ev pansiyonculuğu yapan kadınların } \\
\text { profilinin tespit edilmesi }\end{array}$ & $\begin{array}{c}\text { Gökçeada Yeni Bademli } \\
\text { ve Uğurlu'da ev } \\
\text { pansiyonculuğu yapan } \\
\text { kadınlar }\end{array}$ & $\begin{array}{l}\text { Mülakat ve gözlem } \\
\text { tekniği }\end{array}$ & $\begin{array}{l}\text { Bölge kadınlarının turizm ile şiveleri, yeme- } \\
\text { içmeleri, giyimleri değişime uğramıştır. }\end{array}$ \\
\hline Ekiz Gökmen, (2011) & \begin{tabular}{|c|} 
Turizm sektöründe istihdam edilen \\
yabancı göçmen kadınların işgücü piyasasına \\
eklemlenme sürecinin ve \\
bu süreçte yaşadıkları sorunların incelenmesi
\end{tabular} & $\begin{array}{c}\text { Marmaris'te yaşayan } \\
\text { turizm sektöründe } \\
\text { çalışan yabancı göçmen } \\
\text { kadınlar }\end{array}$ & $\begin{array}{c}\text { Etnografik yöntem, } \\
\text { derinlemesine görüşme, }\end{array}$ & $\begin{array}{l}\text { Göçmen kadınlar bölgede turizm sektöründe } \\
\text { niteliksiz olarak çalıştırılmakta, eksik ücret, fazla } \\
\text { mesai ve tacize maruz kalmaktadırlar. }\end{array}$ \\
\hline Tuncel, (2011) & $\begin{array}{l}\text { Türk basınında turizm haberlerinin cinsellik } \\
\text { ve kadın bedeni üzerinden değerlendirilmesi }\end{array}$ & $\begin{array}{c}\text { Antalya Akdeniz Bölge } \\
\text { Ekleri'nin kadın içerikli } \\
\text { haberleri }\end{array}$ & İçerik analizi, & $\begin{array}{c}\text { Ülkemizde yerli-yabancı turist kadınların cinsel } \\
\text { obje olarak kullanıldığı ve Antalya'da kadın turizm } \\
\text { muhabiri olmadığı belirlenmiştir. }\end{array}$ \\
\hline $\begin{array}{l}\text { Anafarta, Sarvan ve } \\
\text { Yapici, (2008) }\end{array}$ & $\begin{array}{l}\text { Kadın yöneticilerin kariyer } \\
\text { engelleri ve cam tavana ilişkin } \\
\text { algılamalarını incelenmaesi }\end{array}$ & $\begin{array}{l}\text { Konaklama } \\
\text { işletmelerinde çalışan } \\
\text { kadın yöneticiler }\end{array}$ & $\begin{array}{l}\text { Anket, Korelasyon ve } \\
\text { regresyon analizi, }\end{array}$ & $\begin{array}{c}\text { Kadınların büyük çoğunun ücret ve terfi konusunda } \\
\text { ayrımcilığa maruz kaldığı saptanmıştır. }\end{array}$ \\
\hline $\begin{array}{l}\text { Dalkıranoğlu ve } \\
\text { Çetinel, (2008) }\end{array}$ & $\begin{array}{l}\text { Otel departman yöneticilerinin cinsiyeti } \\
\text { ilecinsiyet ayrımcılığına karsı tutumlarının } \\
\text { ilişkisinin incelenmesi }\end{array}$ & \begin{tabular}{|c|} 
İstanbul'daki beş yıldızlı \\
otellerdeki kadın ve \\
erkek yöneticiler
\end{tabular} & Anket, T-testi, & $\begin{array}{l}\text { Kadın ve erkek yöneticilerin cinsiyet ayrımcılığı } \\
\text { konusunda benzer tutumlar sergilediği saptanmıştır. }\end{array}$ \\
\hline $\begin{array}{c}\text { Tükeltürk ve Perçin, } \\
(2008)\end{array}$ & $\begin{array}{c}\text { Kadınların iş hayatlarında yükselmelerine } \\
\text { engel sebeplerin belirlenmesi }\end{array}$ & $\begin{array}{c}\text { Otel işletmelerinde } \\
\text { çalışan kadın yöneticiler }\end{array}$ & $\begin{array}{c}\text { Literatür taramas1, } \\
\text { Ikincil kaynak }\end{array}$ & $\begin{array}{l}\text { Kadınların üst kademelere gelememe sebebinin } \\
\text { altında toplumsal roller yatmaktadır. }\end{array}$ \\
\hline $\begin{array}{l}\text { Demirkol, Fidan ve } \\
\text { Pelit, (2004) }\end{array}$ & $\begin{array}{c}\text { Otel işletmelerinde çalışan kadın işgörenlerin } \\
\text { iş hayatlarında karşılaştıkları sorunların } \\
\text { belirlenmesi }\end{array}$ & $\begin{array}{c}\text { İstanbul, Kocaeli ve } \\
\text { Bursa'da 4-5 yıldızlı } \\
\text { otellerde } 209 \text { kadın } \\
\text { işgören }\end{array}$ & Anket, Frekans analizi & $\begin{array}{c}\text { Kadınların sorunları; İş yükü ve çalışma saatlerinin } \\
\text { fazlalığı, yetki azlı̆ı̆1, Sosyal güvence ve ücret } \\
\text { yetersizliği şeklindedir. }\end{array}$ \\
\hline $\begin{array}{l}\text { Akoğlan Kozak, } \\
\text { (2001) }\end{array}$ & $\begin{array}{l}\text { Konaklama işletmelerinde çalışan kadın } \\
\text { yöneticilerin durumun belirlenmesi }\end{array}$ & $\begin{array}{c}\text { Konaklama } \\
\text { Sektöründeki kadın } \\
\text { yöneticiler }\end{array}$ & Anket & $\begin{array}{l}\text { Kadınların üst düzeyde yeterince temsil } \\
\text { edilmedikleri; görevlerin erkeklere göre daha az, } \\
\text { orta ve kurmay düzeyde olduğu belirlenmiştir. }\end{array}$ \\
\hline Oktik, (2001) & $\begin{array}{c}\text { Kursal kökenli } \\
\text { kadınların turizmden etkileşiminin boyutunun } \\
\text { incelenmesi }\end{array}$ & $\begin{array}{c}\text { Marmaris ve Dalyan } \\
\text { yakınında nüfusu } 600 \text { ile } \\
1100 \text { olan üç köy }\end{array}$ & $\begin{array}{l}\text { Derinlemesine mülakat, } \\
\text { Odak grup görüşmesi, }\end{array}$ & $\begin{array}{l}\text { Erkekler otel işinin kadınlar açısından daha ağır } \\
\text { olduğunu düşünürken kadınlar ise kolay olduğunu, } \\
\text { ailelerine çok vakit ayırdıklarını belirtmişlerdir. }\end{array}$ \\
\hline $\begin{array}{l}\text { Akoğlan Kozak, } \\
\text { (1997) }\end{array}$ & $\begin{array}{l}\text { Kadın yöneticilerin yönetsel davranışları ve } \\
\text { etkinlik algıları arasındaki ilişki incelenmesi }\end{array}$ & $\begin{array}{l}\text { Marmara Bölgesindeki } \\
\text { Kadın Yöneticiler }\end{array}$ & $\begin{array}{l}\text { Anket, Spearmen } \\
\text { Korelasyon Testi }\end{array}$ & $\begin{array}{l}\begin{array}{l}\text { Kadın yöneticilerin demografik özelliklerinde } \\
\text { etkinlik ve davranış boyutuna verdiği önemin } \\
\text { farklılaşığ́ tespit edilmiştir. }\end{array} \\
\end{array}$ \\
\hline Türker, (1997) & $\begin{array}{l}\text { Konaklama işletmelerinde cinsel taciz ve } \\
\text { cinsiyet ayrımının incelenmesi }\end{array}$ & $\begin{array}{c}\text { Ulusal/ uluslararası } \\
\text { cinsel taciz ve cinsiyet } \\
\text { ayrımı literatürü }\end{array}$ & $\begin{array}{l}\text { Literatür taraması, } \\
\text { İkincil kaynak }\end{array}$ & $\begin{array}{l}\text { Türkiye'de cinsel taciz ile ilgili araştırmaya } \\
\text { rastlanmamasına rağmen iş yerlerinde cinsel taciz } \\
\text { olaylarının yüksek olduğu düşünülmektedir. }\end{array}$ \\
\hline $\begin{array}{c}\text { Akoğlan Kozak, } \\
(1996)\end{array}$ & $\begin{array}{c}\text { Konaklama endüstrisinde çalışan kadınların } \\
\text { konumunun incelenmesi }\end{array}$ & $\begin{array}{c}\text { Konaklama } \\
\text { endüstrisindeki kadınlar }\end{array}$ & $\begin{array}{l}\text { Literatür taraması, } \\
\text { İkincil kaynak }\end{array}$ & $\begin{array}{l}\text { Kadın yöneticilerin kariyer engelleri, çalışma } \\
\text { alanları ve ücretleri konusun ele alınmıştır. }\end{array}$ \\
\hline $\begin{array}{l}\text { Akoğlan Kozak, } \\
\text { (1994) }\end{array}$ & $\begin{array}{l}\text { Turizm sektöründe çalışan kadınların } \\
\text { sektördeki dağılımlarının incelenmesi }\end{array}$ & $\begin{array}{c}\text { Yiyecek-İçecek } \\
\text { işletmelerindeki kadın } \\
\text { yöneticiler }\end{array}$ & Anket, Literatür taraması & $\begin{array}{l}\text { Kadın yöneticilerin \% } 50 \text { si sektörde yeterlilikte } \\
\text { erkeklerin gerisinde olduklarını belirtmişlerdir. }\end{array}$ \\
\hline
\end{tabular}

Tablo 5 incelendiğinde turizm sektörü ve kadın konulu makalelerin sayısında 2016 yılından sonra ciddi bir artış yaşandığı görülmektedir. Buna ilaveten makalelerin örneklemleri daha çok konaklama işletmelerinde istihdam edilen kadınlardan oluşmaktadır. Makalelerde sıklıkla turizm sektöründeki kadın girişimcilerin ve kadın 
çalışanların sorunları, cinsiyet ayrımcılığına yönelik yaşadıkları durumlar incelenmiştir. Bulgulardan elde edilen sonuçlar, turizm sektöründe yer alan kadınların cinsiyet ayrımcılığı yaşadıklarını, cam tavan engeline takıldıklarını ve sektörde yeterli düzeyde temsil edilmediklerini göstermektedir.

\subsubsection{Tezler}

Araştırma konusuyla ilgili ulusal düzeyde 23 adet tez hazırlanmıştır. Bu tezlerden 3 tanesi $(\% 13,04)$ doktora, 20 tanesi $(\% 86,96)$ ise yüksek lisans tezidir. Araştırmalar sonucu ilk tezin Akoğlan Kozak'a (1994) ait yayınlanmamış doktora tezi olduğu tespit edilmiştir. Tablo 6 incelendiğinde 1994-2019 yılları arasında hazırlanan tezler bibliyometrik açıdan çeşitli parametrelere göre sınıflandırılarak aktarılmıştır. Ulaşılan tezlerin 4 tanesi vakıf üniversitesi, 19 tanesi devlet üniversitesi tarafından hazırlanmıştır. Araştırma sonucu ulaşılan tezlerin 16'sında nicel araştırma yöntemleri, 7'sinde ise nitel araştırma yöntemleri kullanılmıştır. Veri toplama aracı olarak ağılıklı olarak anket kullanıldığı belirlenmiştir.

Tablo 6: "Turizm ve Kadın” Konuları Üzerine Yazılan Tezler

\begin{tabular}{|c|c|c|c|c|c|c|}
\hline Yazar/Yıl & Tez & Üniversite & Amaç & Araştırma Alanı & Yöntem & Sonuç \\
\hline $\begin{array}{c}\text { Başaran, } \\
\text { (2019) }\end{array}$ & $\begin{array}{l}\text { Yüksek } \\
\text { Lisans }\end{array}$ & $\begin{array}{c}\text { Selçuk } \\
\text { Üniversitesi }\end{array}$ & $\begin{array}{l}\text { Kırsal kalkınma bölgelerinde kadın } \\
\text { istihdamını incelenmesi }\end{array}$ & $\begin{array}{c}\text { Gazlıgöl termal } \\
\text { bölgesinde termal } \\
\text { tesislerde çalışan } \\
\text { kadınlar }\end{array}$ & $\begin{array}{l}\text { Anket ve } \\
\text { mülakat } \\
\text { yöntemi }\end{array}$ & $\begin{array}{c}\text { Kadınlar ekonomik nedenlerden ve iş } \\
\text { imkanının kısıtı olmasından dolayı } \\
\text { çalıştıklarını belirtmişlerdir. }\end{array}$ \\
\hline $\begin{array}{l}\text { Çiçen, } \\
(2019)\end{array}$ & $\begin{array}{l}\text { Yüksek } \\
\text { Lisans }\end{array}$ & $\begin{array}{c}\text { Trakya } \\
\text { Üniversitesi }\end{array}$ & $\begin{array}{c}\text { Kadın çalışanların performansları ve } \\
\text { cinsiyet ayrımcılığı yaşayıp } \\
\text { yaşamadıklarının tespiti }\end{array}$ & $\begin{array}{l}\text { Edirne ili konaklama } \\
\text { işletmelerinde istihdam } \\
\text { edilen kadınlar }\end{array}$ & $\begin{array}{c}\text { Anket, Faktör } \\
\text { Analizi }\end{array}$ & $\begin{array}{l}\text { Kadın çalışanların performansının } \\
\text { yeterli olduğu ve cinsiyet ayrımcılığı } \\
\text { yaşamadıkları tespit edilmiştir. }\end{array}$ \\
\hline Avcl, (2018) & $\begin{array}{l}\text { Yüksek } \\
\text { Lisans }\end{array}$ & $\begin{array}{l}\text { Muğla Sıtkı } \\
\text { Koçman } \\
\text { Üniversitesi }\end{array}$ & $\begin{array}{c}\text { Kadın işgücünün önemi, } \\
\text { karşılaştıkları toplumsal, örgütsel ve } \\
\begin{array}{c}\text { bireysel nedenlerden kaynaklanan } \\
\text { engellere yönelik algılarının } \\
\text { araştırılması }\end{array} \\
\end{array}$ & $\begin{array}{l}\text { Fethiye ilçesi turizm } \\
\text { sektöründe çalışan } \\
\text { kadınlar }\end{array}$ & $\begin{array}{l}\text { Faktör analizi, } \\
\text { korelasyon ve } \\
\text { regresyon } \\
\text { analizi }\end{array}$ & $\begin{array}{l}\text { Kadınlar daha çok alt düzey ve ara } \\
\text { seviyede, mevsimlik, geçici olarak } \\
\text { çalıştırılmaktadır. Eğitim durumu, } \\
\text { pozisyon ve çalışma şekli kadınlara } \\
\text { kariyerlerinde engeldir }\end{array}$ \\
\hline $\begin{array}{l}\text { Demirer, } \\
(2018)\end{array}$ & $\begin{array}{l}\text { Yüksek } \\
\text { Lisans }\end{array}$ & $\begin{array}{c}\text { Nişantaşı } \\
\text { Üniversitesi }\end{array}$ & $\begin{array}{l}\text { Örgüt kültürü ve örgütsel destek } \\
\text { algısının kadın çalışanların cam } \\
\text { tavan engeli algısı arasındaki } \\
\text { ilişkilerin ortaya çıkarıması }\end{array}$ & $\begin{array}{c}\text { İstanbul'da faaliyet } \\
\text { gösteren turizm } \\
\text { işletmelerindeki kadın } \\
\text { çalışanlar }\end{array}$ & \begin{tabular}{|c|} 
Kantitatif \\
yöntem, faktör \\
analizi, \\
güvenilirlik \\
analizi \\
\end{tabular} & $\begin{array}{c}\text { Kadın çalışanların gelir düzeylerinin } \\
\text { artmasıyla, cam tavan engeli algısı } \\
\text { azalmaktadır. }\end{array}$ \\
\hline $\begin{array}{l}\text { Neziroğlu, } \\
\text { (2018) }\end{array}$ & $\begin{array}{l}\text { Yüksek } \\
\text { Lisans }\end{array}$ & $\begin{array}{l}\text { Akdeniz } \\
\text { Üniversitesi }\end{array}$ & $\begin{array}{c}\text { Türk yazılı basınında turizm } \\
\text { sektörüne ait haberlerde kadının ne } \\
\text { şekilde verildiğinin incelenmesi }\end{array}$ & $\begin{array}{l}2015-2018 \text { yılları } \\
\text { arasındaki turizm } \\
\text { haberleri }\end{array}$ & $\begin{array}{c}\text { Basit yargısal } \\
\text { örnekleme, } \\
\begin{array}{c}\text { Teun Van Dijk } \\
\text { analizi }\end{array} \\
\end{array}$ & $\begin{array}{l}\text { Turizm haberlerinde eril dilin hakim } \\
\text { olduğu ve kadının cinsel bir obje } \\
\text { olarak görüldüğü gözlemlenmiştir. }\end{array}$ \\
\hline $\begin{array}{l}\text { Güler, } \\
\text { (2017) }\end{array}$ & $\begin{array}{l}\text { Yüksek } \\
\text { Lisans }\end{array}$ & $\begin{array}{l}\text { Atılım } \\
\text { Üniversitesi }\end{array}$ & $\begin{array}{l}\text { Sürdürülebilir turizmin için yerel } \\
\text { ürünlerin korunmasında kadınların } \\
\text { rolünün belirlenmesi }\end{array}$ & Seferihisar yerel halkı & $\begin{array}{c}\text { Nitel Araştırma } \\
\text { Yöntemleri }\end{array}$ & $\begin{array}{c}\text { Türkiye'nin İlk Cittaslow şehrinde } \\
\text { yaşam kalitesinin, üretimin artmasının } \\
\text { ve göçün engellenmesinde olumlu } \\
\text { sonuçlar saptanmıştır. }\end{array}$ \\
\hline $\begin{array}{l}\text { Özgüven, } \\
\text { (2017) }\end{array}$ & $\begin{array}{l}\text { Yüksek } \\
\text { Lisans }\end{array}$ & $\begin{array}{c}\text { Batman } \\
\text { Üniversitesi }\end{array}$ & $\begin{array}{c}\text { Otel işletmelerinde çalışanların } \\
\text { dindarlık düzeyinin kadının } \\
\text { çalışmasına karşı tutum, öz } \\
\text { kaytarma ve sosyal kaytarma } \\
\text { üzerindeki etkisini incelenmesi } \\
\end{array}$ & $\begin{array}{l}\text { Türkiye'nin } 7 \text { coğrafi } \\
\text { bölgesinde yer alan } \\
\text { turistik otel işletmelerinin } \\
\text { çalışan ve yöneticileri }\end{array}$ & $\begin{array}{c}\text { Anket, tek } \\
\text { yönlü varyans } \\
\text { analizi, ki-kare } \\
\text { analizi }\end{array}$ & $\begin{array}{c}\text { Dindarlık çalışanlar üzerinde } \\
\text { önemlidir. Sosyal kaytarma algısı } \\
\text { demografik değişkenlere göre farklılık } \\
\text { göstermektedir. }\end{array}$ \\
\hline $\begin{array}{l}\text { Akbayırlı, } \\
\text { Kozan, } \\
(2016)\end{array}$ & $\begin{array}{l}\text { Yüksek } \\
\text { Lisans }\end{array}$ & $\begin{array}{l}\text { Dokuz Eylül } \\
\text { Üniversitesi }\end{array}$ & \begin{tabular}{|} 
Kadın turizm akademisyenlerin \\
işyeri arkadaşlıklarının örgüt iklimi \\
ekseninde değerlendirilmesi ve \\
arkadaşlıkların kadınların yaşamına \\
etkilerinin araştırılması
\end{tabular} & $\begin{array}{l}\text { Türkiye'deki devlet } \\
\text { üniversitelerinde } 4 \text { yıllık } \\
\text { fakülte ve yüksekokul } \\
\text { turizm bölümlerindeki } \\
\text { kadın akademisyenler }\end{array}$ & $\begin{array}{l}\text { Derinlemesine } \\
\text { mülakat } \\
\text { tekniği, } \\
\text { Betimsel } \\
\text { analiz tekniği }\end{array}$ & $\begin{array}{c}\text { Kadın yöneticilerin bulunduğu } \\
\text { kurumların hiçbirinde kadın ve erkeğe } \\
\text { farklı politikalar uygulanmamaktadır. } \\
\text { Kadınların kadın çalışanlara ve kadın } \\
\text { yöneticilere bakışı olumludur. }\end{array}$ \\
\hline $\begin{array}{l}\text { Altındal, } \\
(2016)\end{array}$ & Doktora & $\begin{array}{l}\text { Süleyman } \\
\text { Demirel } \\
\text { Üniversitesi }\end{array}$ & $\begin{array}{c}\text { Türkiye turizminde kadın } \\
\text { girişimciliğinin serüveni, } \\
\text { güçlendirme yaklaşımının toplumsal } \\
\text { cinsiyet temelli bakış açısıyla } \\
\text { incelenmesi }\end{array}$ & $\begin{array}{l}\text { Alanya, Kaş, Bodrum ve } \\
\text { Marmaris Ticaret ve } \\
\text { Sanayi Odası, Esnaf ve } \\
\text { Sanatkar Odası } \\
\text { konaklama veme-içme } \\
\text { sektöründeki kadın } \\
\text { girişimciler } \\
\end{array}$ & \begin{tabular}{|} 
Derinlemesine \\
mülakat \\
tekniği, \\
feminist \\
metodoloji,
\end{tabular} & $\begin{array}{c}\text { Ataerkil baskı kadınları engellemekte } \\
\text { ve sektörde var olabilmek için cinsiyet } \\
\text { rollerine daha fazla yönelmektedirler. } \\
\text { Genç yaşta sektöre atılanlar daha } \\
\text { başarılı olmaktadırlar. }\end{array}$ \\
\hline $\begin{array}{l}\text { Bıyıklı, } \\
(2015)\end{array}$ & $\begin{array}{l}\text { Yüksek } \\
\text { Lisans }\end{array}$ & $\begin{array}{c}\text { Atatürk } \\
\text { Unniversitesi }\end{array}$ & $\begin{array}{c}\text { Kadın istihdamının yapısını, } \\
\text { özelliklerini toplumsal cinsiyet ile } \\
\text { ilişkilendirerek iş hayatında } \\
\text { karşılaştıkları ayrımcı uygulamaların } \\
\text { incelenmesi }\end{array}$ & $\begin{array}{l}\text { Atatürk Üniversitesi } \\
\text { Turizm Fakültesi ve } \\
\text { Erzurum MYO } \\
\text { öğrencileri }\end{array}$ & $\begin{array}{c}\text { Anket, } \\
\text { Güvenilirlik } \\
\text { analizi,Ki-kare } \\
\text { analizi }\end{array}$ & $\begin{array}{l}\text { Kadınların çalışma alanlarının } \\
\text { toplumsal cinsiyet rollerine göre } \\
\text { şekillendiği ve erkek/kadın işi ayrımı } \\
\text { açıkça ortaya konmuştur. }\end{array}$ \\
\hline $\begin{array}{l}\text { Fidan, } \\
(2015)\end{array}$ & $\begin{array}{l}\text { Yüksek } \\
\text { Lisans }\end{array}$ & $\begin{array}{l}\text { Beykent } \\
\text { Üniversitesi }\end{array}$ & $\begin{array}{l}\text { Turizm sektöründe çalışanların } \\
\text { cinsiyet farkııııkları, kariyer } \\
\text { öncelikleri ve iş koşullarına } \\
\text { duyarlıı̆ıııın belirlenmesi }\end{array}$ & $\begin{array}{l}\text { İstanbul ilinde bulunan } \\
\text { otellerde çalışan } \\
\text { yöneticiler }\end{array}$ & \begin{tabular}{|c|} 
Anket, \\
Kruskall Wallis \\
ve Mann \\
Whitney \\
testleri
\end{tabular} & $\begin{array}{c}\text { Cinsiyet ayrımcılığı kadınların yönetici } \\
\text { pozisyonlarına gelmelerine engeldir.. } \\
\text { Kadınlar kariyerlerinde erkekleri engel } \\
\text { olarak görmektedirler. }\end{array}$ \\
\hline
\end{tabular}


Tablo 6'nın devamı

\begin{tabular}{|c|c|c|c|c|c|c|}
\hline $\begin{array}{l}\text { Güleç, } \\
\text { (2015) }\end{array}$ & $\begin{array}{l}\text { Yüksek } \\
\text { Lisans }\end{array}$ & $\begin{array}{c}\text { Adnan } \\
\text { Menderes } \\
\text { Üniversitesi } \\
\end{array}$ & \begin{tabular}{|c|} 
Kadın çalışanların cam tavan \\
sendromunun örgütsel vatandaşlığa \\
etkilerinin araştııılması
\end{tabular} & $\begin{array}{c}\text { Kuşadası'ndaki } 4 \text { ve } 5 \\
\text { yıldızlı otellerdeki kadın } \\
\text { işgörenler }\end{array}$ & $\begin{array}{c}\text { Anket, T-testi, } \\
\text { ANOVA }\end{array}$ & $\begin{array}{l}\text { Kadınlar çoğunlukla alt düzey çalışan } \\
\text { kadrosunda istihdam edildiği } \\
\text { gözlemlenmiştir. }\end{array}$ \\
\hline $\begin{array}{l}\text { Köse, } \\
(2014)\end{array}$ & $\begin{array}{l}\text { Yüksek } \\
\text { Lisans }\end{array}$ & $\begin{array}{l}\text { Hacettepe } \\
\text { Üniversitesi }\end{array}$ & $\begin{array}{c}\text { Turizmde kadın girişimciliği ve } \\
\text { istihdamının toplumsal cinsiyet } \\
\text { rolleri üzerindeki etkisi incelenmesi }\end{array}$ & $\begin{array}{l}\text { Ankara Beypazarı'nda } \\
\text { turizm sektöründe } \\
\text { çalışan kadınlar }\end{array}$ & $\begin{array}{l}\text { Odak grup } \\
\text { görüşmesi, } \\
\text { İçerik analizi }\end{array}$ & $\begin{array}{c}\text { Turizmin kadınların çalışmasını } \\
\text { olumlu etkilediği, girişimcilik alanında } \\
\text { hala sınırlı oldukları ve kendilerini } \\
\text { önce anne ve eş, sonra çalışan kadın } \\
\text { olarak tanımakta oldukları } \\
\text { gözlenmiştir. }\end{array}$ \\
\hline $\begin{array}{l}\text { Mayuk, } \\
(2013)\end{array}$ & $\begin{array}{l}\text { Yüksek } \\
\text { Lisans }\end{array}$ & $\begin{array}{l}\text { Balıkesir } \\
\text { Üniversitesi }\end{array}$ & $\begin{array}{c}\text { Kadınların çalışma yaşamında } \\
\text { karşılaşstıkları kariyer engelleri, } \\
\text { nedenleri, etkileri ve sonuçları } \\
\text { incelenmiştir. }\end{array}$ & \begin{tabular}{|c|} 
İstanbul'daki $4-5$ yıldızlı \\
otellerde orta ve üst \\
düzey yönetici \\
pozisyonunda çalışanlar
\end{tabular} & $\begin{array}{l}\text { Anket,Ki-kare, } \\
\text { T-testi ve } \\
\text { ANOVA }\end{array}$ & $\begin{array}{l}\text { Konaklama işletmelerinde kadın } \\
\text { yöneticilerin kariyer engelleriyle } \\
\text { karşılaştıkları bunun da cam tavan } \\
\text { sendromuna yol açtığı saptanmıştır. }\end{array}$ \\
\hline $\begin{array}{l}\text { Çamlıbel, } \\
(2010)\end{array}$ & $\begin{array}{l}\text { Yüksek } \\
\text { Lisans } \\
\text { Tezi }\end{array}$ & $\begin{array}{l}\text { Sakarya } \\
\text { Üniversitesi }\end{array}$ & $\begin{array}{c}\text { Otel işletmelerinde çalışan } \\
\text { kadınların iş değiştirmelerine etken } \\
\text { olan sebepler incelenmesi. }\end{array}$ & $\begin{array}{c}\text { İstanbul'da } 5 \text { Yıldızlı } \\
\text { otellerdeki kadın } \\
\text { çalışanlar }\end{array}$ & $\begin{array}{l}\text { Anket, } \\
\text { Korelasyon } \\
\text { Analizi }\end{array}$ & $\begin{array}{l}\text { Kadınların yaşadığı iş güçlüklerinin iş } \\
\text { değiştirme niyeti üzerinde etkili } \\
\text { olduğu sonucu elde edilmiştir. }\end{array}$ \\
\hline $\begin{array}{l}\text { Tuncel, } \\
(2009)\end{array}$ & $\begin{array}{l}\text { Yüksek } \\
\text { Lisans }\end{array}$ & $\begin{array}{l}\text { Selçuk } \\
\text { Üniversitesi }\end{array}$ & $\begin{array}{r}\text { Kadınların ha } \\
\text { sayfaları } \\
\text { doldurdu }\end{array}$ & $\begin{array}{l}\text { Antalya'da yayın yapan } \\
\text { üç yerel gazetenin ekleri }\end{array}$ & $\begin{array}{l}\text { Yüz } \\
\text { gör } \\
\text { tek }\end{array}$ & $\begin{array}{l}\text { Medyada kadına cinsiyetçi bir bakış } \\
\text { hakim olmuştur. }\end{array}$ \\
\hline $\begin{array}{l}\text { Tümen, } \\
(2009)\end{array}$ & $\begin{array}{l}\text { Yüksek } \\
\text { Lisans }\end{array}$ & $\begin{array}{l}\text { Mersin } \\
\text { Üniversitesi }\end{array}$ & $\begin{array}{c}\text { Turizm alanındaki üniversite } \\
\text { öğrencilerinin ayrımcı uygulamalar } \\
\text { ve iş tercihleriyle ilgili tutumlarının } \\
\text { incelenmesi } \\
\end{array}$ & $\begin{array}{c}\text { Mersin Üniversitesi } \\
\text { Turizm İşletmeciliği ve } \\
\text { Otelcilik Yüksekokulu 3. } \\
\text { ve 4. Sınıf öğrencileri } \\
\end{array}$ & $\begin{array}{l}\text { Anket, T testi, } \\
\text { Frekans } \\
\text { analizi }\end{array}$ & $\begin{array}{c}\text { Erkek öğrenciler kadın/erkek işi } \\
\text { ayrımı yapılmasını ve kadınların } \\
\text { toplumsal cinsiyet rollerine uygun } \\
\text { işlerde çalışmalarını belirtmişlerdir. }\end{array}$ \\
\hline $\begin{array}{l}\text { Güzel, } \\
\text { (2009) }\end{array}$ & Doktora & $\begin{array}{l}\text { Dokuz Eylül } \\
\text { Üniversitesi }\end{array}$ & $\begin{array}{l}\text { Kadınların karşılaştığı kariyer } \\
\text { engellerinin örgütsel bağlııklarını } \\
\text { etkileme düzeyinin ölçülmesi. }\end{array}$ & $\begin{array}{c}\text { Kuşadası'ndaki4 ve } 5 \\
\text { yıldızlı otellerde çalışan } \\
\text { kadınlar }\end{array}$ & $\begin{array}{l}\text { Anket, T-testi, } \\
\text { Varyans } \\
\text { analizi, ikincil } \\
\text { kaynaklar }\end{array}$ & $\begin{array}{c}\text { Kadınların d özelliklerinin } \\
\text { kariyerlerinde etkili olduğu, engellerle } \\
\text { karşılaştıklarında örgütsel } \\
\text { bağlılıklarının arttığı ve mücadeleci } \\
\text { tavır sergiledikleri gözlemlenmiştir. }\end{array}$ \\
\hline $\begin{array}{l}\text { Gebelek, } \\
(2008)\end{array}$ & $\begin{array}{l}\text { Yüksek } \\
\text { Lisans }\end{array}$ & $\begin{array}{c}\text { Koç } \\
\text { Üniversitesi }\end{array}$ & $\begin{array}{c}\text { Türkiye'ye kadın göçlerin sebepleri, } \\
\text { toplumda var olma ve kendilerine } \\
\text { farklı kimlik yaratma çabalarının } \\
\text { incelenmesi }\end{array}$ & $\begin{array}{l}\text { Antalya'da Sovyet } \\
\text { Ülkelerinden gelen } \\
\text { turizm endüstrisinde } \\
\text { çalışan kadınlar }\end{array}$ & \begin{tabular}{|c|} 
Anket, \\
Gözlem, \\
Derinlemesine \\
görüşme \\
tekniği \\
\end{tabular} & $\begin{array}{l}\text { Göçmen kadınların çalıştıkları iş } \\
\text { kollarının dinamiklerine göre turizmin } \\
\text { önemli olduğu ve topluma entegre } \\
\text { önemli rol oynadığı saptanmıştır. }\end{array}$ \\
\hline $\begin{array}{l}\text { Sezen, } \\
(2008)\end{array}$ & $\begin{array}{l}\text { Yüksek } \\
\text { Lisans }\end{array}$ & $\begin{array}{l}\text { Çanakkale } \\
\text { Onsekiz Mart } \\
\text { Üniversitesi }\end{array}$ & $\begin{array}{l}\text { Cam tavan sendromunun } \\
\text { boyutlarının tespiti, nedenleri ve } \\
\text { sonuçlarının incelenmesi }\end{array}$ & $\begin{array}{r}\text { İstan } \\
\text { göster } \\
\text { otel } \\
\text { kadır }\end{array}$ & $\begin{array}{c}\text { Anket, Faktör } \\
\text { analizi, }\end{array}$ & $\begin{array}{c}\text { Çalışan kadınların çok fazla ailevi } \\
\text { sorumluluklar üstlendiği ve bununda } \\
\text { kariyerlerine engel teşkil ettiği } \\
\text { gözlemlenmiştir. }\end{array}$ \\
\hline $\begin{array}{l}\text { Dalkıranoğl } \\
\text { u, (2006) }\end{array}$ & $\begin{array}{l}\text { Yüksek } \\
\text { Lisans }\end{array}$ & $\begin{array}{l}\text { Eskişehir } \\
\text { Anadolu } \\
\text { Üniversitesi }\end{array}$ & $\begin{array}{c}\text { Otel yöneticilerinin cinsiyeti ile } \\
\text { cinsiyet ayrımcılığına karşı tutumları } \\
\text { arasındaki ilişki incelenmesi }\end{array}$ & $\begin{array}{l}\text { İstanbul'daki } 5 \text { yıldızlı } \\
\text { otel işletmelerindeki } \\
\text { kadın ve erkek } \\
\text { departman yöneticileri }\end{array}$ & $\begin{array}{l}\text { Anket, } \\
\text { Frekans } \\
\text { analizi, }\end{array}$ & $\begin{array}{c}\text { Yöneticinin cinsiyetinin kadın çalışana } \\
\text { karşı ayrımcı tavrının önleyici, bakış } \\
\text { açısının iyileştirici etkisinin olduğu } \\
\text { tespit edilmiştir. }\end{array}$ \\
\hline $\begin{array}{l}\text { Elmas, } \\
(2002)\end{array}$ & $\begin{array}{l}\text { Yüksek } \\
\text { Lisans }\end{array}$ & $\begin{array}{l}\text { Orta Doğu } \\
\text { Teknik } \\
\text { Üniversitesi }\end{array}$ & $\begin{array}{c}\text { Turizmde işgücünü oluşturan } \\
\text { kadınların sektörün yarattığı iş } \\
\text { olanaklarının cinsiyete dayalı } \\
\text { işbölümünü güçlendirip } \\
\text { güçlendirmediğinin incelenmesi }\end{array}$ & $\begin{array}{l}\text { Kapadokya bölgesinde } \\
20 \text { işyerinde işveren ve } \\
\text { çalışan kadın ve erkekler }\end{array}$ & $\begin{array}{c}\text { Kantitatif(nicel } \\
\text { Jyöntem ve } \\
\text { Kalitatif (nitel) } \\
\text { yöntem }\end{array}$ & $\begin{array}{l}\text { Turizm sektörünün kadın iş gücü için } \\
\text { fırsatları çok olsa da sosyal, kültürel } \\
\text { ve ekonomik bağımsızlığın tatmin } \\
\text { edici düzeyde olmadığı saptanmıştır. }\end{array}$ \\
\hline $\begin{array}{l}\text { Akoğlan, } \\
\text { (1994) }\end{array}$ & Doktora & $\begin{array}{c}\text { Gazi } \\
\text { Üniversitesi }\end{array}$ & $\begin{array}{c}\text { Kadın yöneticilerin konumları, } \\
\text { eğitimleri, kariyer engelleri ve } \\
\text { yoğunlaştıkları çalışma alanlarının } \\
\text { incelenmesi }\end{array}$ & $\begin{array}{c}\text { Konaklama sektöründeki } \\
\text { kadın Yöneticiler }\end{array}$ & $\begin{array}{c}\text { Anket, } \\
\text { Spearmen } \\
\text { Korelasyon } \\
\text { testi } \\
\end{array}$ & $\begin{array}{c}\text { Kadın yöneticilerin etkinlik ve } \\
\text { davranış boyutuna verdiği önemin } \\
\text { farklılaştığı, etkinlik algılamaları } \\
\text { tercihlerinin benzeştiği belirlenmiştir. }\end{array}$ \\
\hline
\end{tabular}

Tablo 6 incelendiğinde tezlerin yıllara göre dağılımı 2015 yılı itibariyle ivmelenmeye başlamıştır. Ulaşılan tezlerin \% 86,96'sının yüksek lisans tezi olduğu, özellikle doktora alanında yapılan çalışmaların oldukça düşük oranda olduğu tespit edilmiştir. Yapılan tez çalışmalarının daha çok bulundukları bölge/kenti kapsayan nitelikte çalışmalar olduğu belirlenmiştir.

Tablo 7: “Turizm ve Kadın” Konulu Tezlerin Yazarlarının Cinsiyetleri

\begin{tabular}{|c|c|c|c|}
\hline \multicolumn{2}{|c|}{ Kadın Yazarlar } & \multicolumn{2}{c|}{ Erkek Yazarlar } \\
\hline Sayı & Yüzde \% & Sayı & Yüzde \% \\
\hline $\mathbf{2 0}$ & $\% 86,96$ & 3 & $\% 13,04$ \\
\hline
\end{tabular}

Tablo 7 verileri incelendiğinde turizm ve kadın konulu ulusal alanyazında ulaşılan tezlerin büyük bir çoğunluğu $(\% \quad 86,96)$ kadın yazarlar tarafından hazırlanmıştır. Turizmde kadın olgusunun tez düzeyinde de yine kadınlar tarafından inceleniyor olması, benzer şekilde makale yazarlarının çoğunun kadın olması gibi dikkat çekicidir.

\subsubsection{Kitaplar}

Türkiye'de alanyazında "turizm ve kadın" anahtar kelimeleri tarandığında Tablo 8'deki sonuçlar elde edilmiştir. 
Tablo 8: “Turizm ve Kadın” Konuları Üzerine Yazılan Kitaplar

\begin{tabular}{|l|l|l|}
\hline Yazar/Yıl & Kitabın Adı & Yayın Evi, Basım yeri \\
\hline $\begin{array}{l}\text { Bayram, Bayram, Sürücü } \\
\text { (2018) }\end{array}$ & Turizm ve Kadın & Detay Yayıncılık, Ankara \\
\hline Çelebi (1997) & $\begin{array}{l}\text { Turizm Sektöründeki Küçük } \\
\text { İşyeri Örgütlerinde Kadın } \\
\text { Girişimciler }\end{array}$ & $\begin{array}{l}\text { T.C. Başbakanlık Kadının Statüsü } \\
\text { ve Sorunları Genel Müdürlüğü, } \\
\text { Ankara }\end{array}$ \\
\hline
\end{tabular}

Araştırma bulgularına göre sadece iki adet kitapta "turizm ve kadın" konuları birlikte ele alınmıştır. İlk kitap 1997 yılında ikinci kitap ise 2018 yılında yayımlanmıştır. $\mathrm{Bu}$ durum ulusal alanyazında kitap düzeyinde konunun çok az incelendiğinin göstergesidir.

\subsubsection{Bildiriler}

$\mathrm{Bu}$ çalışma sonucunda ulusal alanyazında turizm ve kadın konulu 14 adet bildiriye ulaşılmıştır. İlk bildiri 2007 yılında yayınlanmıştır. Ulaşılan bildiriler yöntem, alan ve bulgular gibi parametrelere göre sınıflandırılarak Tablo 9'da aktarılmıştır.

Tablo 9: "Turizm ve Kadın” Konuları Üzerine Yapılan Bildiriler

\begin{tabular}{|c|c|c|c|}
\hline Yazar/Yıl & Araştırma Alanı & Yöntem & Sonuç \\
\hline $\begin{array}{l}\text { Özmen, Bilgin ve Ubbelohde, } \\
(2018)\end{array}$ & $\begin{array}{l}\text { Sakarya ilinde } 3,4 \text { ve } 5 \text { yıldızlı } 18 \text { otel } \\
\text { işletmesinde } 8 \text { üst düzey kadın } \\
\text { yönetici }\end{array}$ & $\begin{array}{l}\text { Yüz yüze görüşme } \\
\text { tekniği, Betimsel ve İ̧̧erik } \\
\text { analizi }\end{array}$ & $\begin{array}{l}\text { Araştırmada erkek yöneticilerin çoğunlukta olduğu, } \\
\text { kadınların duygusal zeka empati kurma, gibi özelliklerinin } \\
\text { sektörde rekabetçi yapıyı arttırdığı tespit edilmiştir. }\end{array}$ \\
\hline Akarsu ve Akça, (2017) & Yozgat Bölgesindeki Termal tesisler & İkincil Kaynak & $\begin{array}{l}\text { Yozgat bölgesindeki turizm tesislerinin kadınların } \\
\text { kullanımına uygun ve gidilecek yerler haline gelmesine } \\
\text { katkı sağlanmıştır. }\end{array}$ \\
\hline Gül ve Gül, (2017) & $\begin{array}{l}\text { Balıkesir'de yiyecek içecek } \\
\text { sektöründeki kadın girişimciler }\end{array}$ & $\begin{array}{l}\text { Anket, Frekans Analizi ve } \\
\text { T-testi }\end{array}$ & $\begin{array}{l}\text { Kadınların iş kurma sürecinde en çok eşlerinden destek } \\
\text { aldıkları ve ekonomik risk algılarının yüksek olduğu } \\
\text { saptanmıştır. }\end{array}$ \\
\hline Kavak ve Kayg & $\begin{array}{l}\text { Kars ili ve Sarıkamış ilçesindeki } 4 \\
\text { yıldızlı otellerde görevli çalışanlar }\end{array}$ & $\begin{array}{l}\text { Anket, Faktör analizi, } \\
\text { Korelasyon ve Regresyon } \\
\text { analizleri }\end{array}$ & $\begin{array}{l}\text { Medeni durumun toplumsal cinsiyet algısı ile anlamlı } \\
\text { farklıı oluşturduğu bu durumun da bekarların evlilere } \\
\text { oranla toplumsal cinsiyet algılarının yüksekliğinden } \\
\text { kaynaklandığı tespit edilmiştir. }\end{array}$ \\
\hline Savgın ve Göktürk, (2017) & 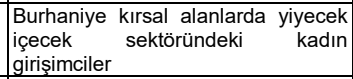 & $\begin{array}{l}\text { Yüz yüze görüşme, } \\
\text { Betimsel analiz }\end{array}$ & $\begin{array}{l}\text { Kadınların mesleki bilgi ve deneyimi olmadığı, kırsal } \\
\text { alanda girişimcilikte bulunan kadınlara destek } \\
\text { mekanizmalarının ulaşmadığı tespit edilmiştir. }\end{array}$ \\
\hline \begin{tabular}{|l} 
Sürücü, Kargiglioğlu ve Ak, \\
$(2017)$
\end{tabular} & Beypazarı'ndaki kadınlar & İkincil kaynak & $\begin{array}{l}\text { Kadınların üretime katıldıkları, ailelerine mutfak ve el } \\
\text { sanatları alanında ekonomik katkı sağladıkları sonucuna } \\
\text { varımıştır }\end{array}$ \\
\hline $\begin{array}{l}\text { Tunçsiper, Özkan ve Boz, } \\
(2017)\end{array}$ & Nusratı Köyünde Yaşayanlar & $\begin{array}{l}\text { Yüz yüze görüşme, } \\
\text { Betimsel Analiz }\end{array}$ & $\begin{array}{l}\text { Kırsal turizm faaliyeti ekonomik katkı sağlamış ve ve } \\
\text { girişimcilik yönleri ortaya çıkmıştır. Farkı ürünler üretme } \\
\text { istekleri doğmuş ve kendilerine güvenleri artmıştır. }\end{array}$ \\
\hline $\begin{array}{l}\text { Kanten, Yeşiltaş ve Akdağ, } \\
(2014)\end{array}$ & Antalya'daki 5 yıldızlı 4 otel & $\begin{array}{l}\text { Korelasyon ve Regresyon } \\
\text { analizi }\end{array}$ & $\begin{array}{l}\text { İş- aile, çevre ve cinsiyet ayrımcılığından dolay } \\
\text { mutluluk düzeyleri ve kariyer motivasyonların } \\
\text { etkilendiği belirlenmiştir }\end{array}$ \\
\hline $\begin{array}{l}\text { Şahin, Sönmez, Kazoğlu, } \\
\text { Saygı,(2014) }\end{array}$ & $\begin{array}{l}\text { Antalya il ve ilçelerinde } 4 \text { ve } 5 \text { yıldızlı } \\
\text { otellerde çalışan kadınlar }\end{array}$ & $\begin{array}{l}\text { Anket, Faktör analizi, T- } \\
\text { testi }\end{array}$ & $\begin{array}{l}\text { İş hayatında cinsiyet ayrımcılığına maruz kalan kadınların } \\
\text { kariyer beklentileri düşmekte, kariyerlerini sonlandırma } \\
\text { eğilimleri artmaktadır. }\end{array}$ \\
\hline Güçer, Yayla ve Koç, (2013) & Ankara il sınırı TÜIKK 2011 verileri & $\begin{array}{l}\text { Anket, } \\
\text { T-testi, ANOVA }\end{array}$ & $\begin{array}{l}\text { Turizm faaliyetleri cinsiyet kimliği açısından, feminen ve } \\
\text { maskülen mesajlar barındıran reklam yapan işletmelere } \\
\text { göre hedef kitlenin belirlendiği görülmüştür. }\end{array}$ \\
\hline Ülkü, Erol ve Köroğlu, (2013) & $\begin{array}{l}\text { İstanbul çıkışı paket turları satın } \\
\text { almış kadın tüketiciler }\end{array}$ & $\begin{array}{l}\text { Anket, Te } \\
\text { analizi ve }\end{array}$ & $\begin{array}{l}\text { Kadın tüketicilerin medeni hal ve c } \\
\text { durumlarının ürün satın alırken etkili olc }\end{array}$ \\
\hline \begin{tabular}{|l|} 
Tosun, Bilim, Cihangir, Gökçe \\
ve Kocabozdoğan, (2011)
\end{tabular} & İskenderun'daki kadınlar & Anket & $\begin{array}{l}\begin{array}{l}\text { Kadınların turizm sektöründe çalışmaya çok olumlu } \\
\text { baktıkları görülmüştür. }\end{array} \\
\end{array}$ \\
\hline $\begin{array}{|lr|}\text { Tosun, Gökçe, Bilim, } \\
\text { Kocabozdoğan Çalkın, Babat, } \\
\text { (2011) }\end{array}$ & Samandağ'daki kursiyerler & Anket & $\begin{array}{l}\text { Kursiyerlerin turizm sektörüne ve sektörde çalışmaya çok } \\
\text { olumlu baktıkları, turizmi uzun yıllar çalışabilecekleri bir } \\
\text { sektör olarak gördükleri tespit edilmiştir. }\end{array}$ \\
\hline $\begin{array}{l}\begin{array}{l}\text { Aydın, Özkul, Tandoğan ve } \\
\text { Şahin, (2007) }\end{array} \\
\end{array}$ & $\begin{array}{l}\text { Otel işletmelerinde orta ve üst } \\
\text { kademe kadın yöneticiler }\end{array}$ & Anke & $\begin{array}{l}\text { Otel işletmelerindeki kadınların ciddi bir cam tavan ile karşı } \\
\text { karşıya oldukları gözlemlenmiştir. }\end{array}$ \\
\hline
\end{tabular}

Ulaşılan bildirilerin yarısında nitel, diğer yarısında ise nicel araştırma yöntemleri kullanılmıştır. Çalışmaların sadece iki tanesi ikincil kaynaklar kullanılarak yapılan literatür araştırmasını kapsamaktadır. Bildirilerde genellikle turizm sektöründeki kadınların sorunları işletmeler ve kentler bazında ele alınmıştır. Bulgulardan elde edilen 
sonuçlar, kadınların turizm sektöründe çalışmanın avantaj ve dezavantajlarının farkında olduklarını göstermektedir. Kadınların cinsiyet ayrımcılığı yaşadıkları, cam tavan engeline maruz kaldıkları, yönetim kademelerinde yeterince yer almadıkları gibi olumsuz unsurların yanı sıra sektörün girişimcilik yönlerini ortaya çıkarması ve toplumsal cinsiyet eşitliğine katkı yapması gibi olumlu yansımaları olduğu da belirlenmiştir.

\section{Sonuç}

Bir sektöre ait performansın etkin değerlendirilebilmesi için mikro ve makro bazlı analiz yapılması önemlidir(Bustillo, Fernandez-Macias, Anton ve Esteve,2011:448). Bilim dallarının mevcut durumlarının belirlenmesinde önemli rol oynayan bibliyometrik çalışmalar, araştırmacılara söz konusu alanlara ilişkin kapsamlı bilgi sağlamaktadır. Bu bağlamda çalışma; "turizm ve kadın" olgularını birlikte ele alan ulusal çalışmaların bibliyometrik analiz ile incelenmesini amaçlamıştır. Turizm sektöründe kadın işgücünün fazla olması ve turizmin "emek-yoğun" olduğu kadar "kadın-yoğun" iş alanı özelliği taşıması çalışma alanını seçme konusunda etkili olmuştur. Çalışmanın "turizm ve kadın" konusunda alanyazına katkı sağlaması ve gelecek araştırmalar için bir kaynak niteliği taşıması hedeflenmiştir.

Çalışma kapsamında yapılan bibliyometrik araştırma sonucu ulusal alanyazın veri tabanlarında yayınlanmış çalışmalar tez, makale, bildiri ve kitap başlıkları altında incelenmiş, 85 akademik çalışmaya ulaşılmıştır. Araştırma bulguları "turizm ve kadın" konuları birlikteliğinin özellikle 2016 yılından itibaren ivme kazandığını göstermektedir. Turizm ile Toplumsal Cinsiyet ve Kadın Çalışmaları Anabilim Dalları YÖK nezninde doçentlik alanı olarak kabul edilmektedir. Bu durum son dönemlerde bu konulara yönelik gerçekleştirilen akademik çalışmaların sayısının artmasını açıklamaktadır.

Araştırmada elde edilen önemli bulgulardan biri; ulusal düzeyde "turizm ve kadın" olgularını kapsayan bilimsel çalışma sayısının turizm sektöründeki diğer alanlara (girişimcilik, kırsal turizm vb) kıyasla az olduğudur. Ancak kadınların yoğun ve aktif olarak rol aldıkları turizm sektöründe kadın çalışanların sorunlarını ortaya koyan ve çözüm önerileri sunan akademik çalışmaların sayısı gün geçtikçe artmaktadır. Buna rağmen uluslararası alanyazında turizm ve kadın konularını kapsayan teorik açıdan daha geniş bir literatür mevcuttur.

Bibliometrik analiz bulgularına göre elde edilen çalışmaların; turizmde kadın işgücünün yüksek olduğu ancak kadınların erkeklerden daha alt pozisyonlarda istihdam edildikleri, daha düşük ücrete maruz kaldıkları, kadın yönetici oranının yetersiz olduğu, kadınların genellikle kat hizmetlerinde istihdam edildiği ve kırsal turizmde kadın girişimciliğinin daha yüksek olduğu şeklinde yoğunlaştığı görülmüştür. Elde edilen çalışmalar öncelikle kadın girişimciliği, daha sonra cinsiyet ayrımcılığı ve cam tavan sendromu konularını kapsamaktadır. Buna ilaveten çalışmalarda; turizm sektöründeki kadınların cinsiyet ayrımcılığı yaşamasının performanslarını olumsuz etkilediği, performansları ve demografik özellikleri arasında ilişkiler olduğu tespit edilmiştir.

Araştırma sonucunda "turizm ve kadın" konularını kapsayan en fazla sayıdaki akademik çalışma türünün makale ve ardından lisans üstü tezler olduğu görülmüştür. Lisans üstü çalışma olarak yüksek lisans düzeyinde üretilen tez sayısı daha fazla olmasına rağmen özellikle doktora düzeyinde çalışma sayısının düşük olması nedeni ile yazılacak yeni doktora tezlerinin alanyazına ciddi katkı yapacağı düşünülmektedir. Makale ve tezlerin yazarlarının cinsiyetlerine yönelik bir projeksiyon; turizm alanyazınında kadın olgusunun çoğunlukla kadın yazarlar tarafından ele alındığını göstermektedir. Makalelerin büyük çoğunluğu $(\% 65,22)$ çoklu yazarlı çalışmalardır. Bu 
araştırma kapsamında konu ile ilgili Türkiye'de yayınlanan kitap sayısının sadece 2 adet olması ulusal kitap açısından eksiklik olarak değerlendirilebilir. Araştırmada kitap bölümleri kapsam dışı tutulmuştur. Akademik süreli yayınlarda, özel olarak "turizm ve kadın" konulu dergilere rastlanılmamıştır. Bu alandaki çalışmaların çoğunlukla genel turizm konulu dergilerde yayımlandığı tespit edilmiştir. Ulaşılan çalışmalarda sıklıkla nicel, ardından ise nitel araştırma yöntemlerini kapsadığı belirlenmiştir. Az sayıda çalışma ikincil kaynak kullanılarak kullanılarak yapılan literatür taramasını ve Swot analizini içermektedir. Çalışmaların büyük çoğunluğunda veri toplama yöntemlerinden anket uygulaması gerçekleştirilmiştir. Elde edilen çalışmalarının sıklıkla yazar/yazarların bulundukları bölge/kenti kapsayan nitelikte çalışmalar olduğu belirlenmiştir. Araştırma neticesinde elde edilen ulusal düzeyde yazılmış makalelerin \%56,52'sinde ağırlıklı olarak yabancı kaynaklar kullanılmıştır.

Her çalışmada olduğu gibi bu çalışmada da bazı sınırlılıklar söz konusudur. İlk olarak çalışma; zaman açısından sınırlandırılmış ve 2019 yılının Nisan-Mayıs-Haziran aylarında gerçekleştirilmiştir. İkinci olarak çalışma kaynaklara erişebilirlik açısından sınırlandırılmış, örneklem sadece çevrimiçi erişimi sağlanabilen ve ulusal veri tabanlarında yayınlanan akademik kaynaklardan faydalanılarak oluşturulmuştur.

Çalışmanın, turizm sektöründeki kadınları inceleyen araştırmalar açısından veri olduğu düşünülmektedir. Buna ilaveten çalışma araştırmacılara ve sektöre yönelik birtakım önerileri de beraberinde getirmektedir. Alanyazın taraması sonucunda turizm sektöründe önemli yeri olan kadınlar için ulusal düzeyde "turizm ve kadın" konularını birlikte ele alan bilimsel çalışmaların çok fazla olmadığı tespit edilmiştir. Bu bağlamda "turizm ve kadın" konularında yapılacak araştırmaların çeşitlendirilmesi ve artırılması alanyazını güçlendirecektir. Gelecek çalışmaların ulusal ve uluslararası tüm kaynakları dahil edecek şekilde genişletilmesi karşılaştırma imkanı sunabilir. Çalışma turizm sektöründe çalışan kadınların mevcut durumunu, sorunlarını ve cinsiyet ayrımcılığı gerçeğini ortaya koymaktadır. Bu doğrultuda sektörde kadınların yaşadıkları sorunları çözmek, cinsiyet ayrımcılığını giderebilmek, eşit işe eşit ücret alabilmelerini sağlamak, terfi olanaklarını geliştirmek vb konularda üretilecek politikalara rehber niteliğindedir. Turizmde yaşanan cinsiyet eşitsizliğini gidermek için eğitim, araştırma ve politikalarda toplumsal cinsiyet eşitliği temelli yaklaşım gerekli gözükmektedir.

\section{Kaynakça}

Akarsu Höbek, R. ve Akça Kılıç, N. (2017), 'Yozgat Bölgesinde Termal Turizm ve Kadın', II. Uluslararası Bozok Sempozyumu Yozgat'ın Turizm Potansiyelleri Sorunları Bildiri Kitabı, ss.148-156.

Akbayırlı Kozan, Y. G. (2016), Kadın Turizm Akademisyenlerinin İşyeri Arkadaşlıklarının Örgüt İklimi Ekseninde Analizi, Yüksek Lisans Tezi, Dokuz Eylül Üniversitesi, Sosyal Bilimler Enstitüsü, İzmir.

Akoğlan, M. (1994), Konaklama Sektöründe Kadın Yöneticilerin Yönetsel Davranışları ile Etkinlik Algılamaları İlişkisi Üzerine Bir Araştırma, Yayınlanmamış Doktora Tezi, Gazi Üniversitesi, Sosyal Bilimler Enstitüsü, Ankara.

Akoğlan, M. (1994), 'Turizm Sektöründe Yönetici Kadınlar', Anatolia Turizm Araştırmaları Dergisi, 5(1), ss.48-49.

Akoğlan Kozak, M. (1996). 'Konaklama Endüstrisinde Kadının Konumu', Anatolia Turizm Araştırmaları Dergisi, 7(2), ss.16-23.

Akoğlan Kozak M. (1997), 'Konaklama Endüstrisinde Kadın Yöneticilerin Yönetsel Davranışları ve Etkinlik Algılamalarının Analizi', TUGEV Turizmde Seçme Makaleler:27, ss.1-27, İstanbul. 
Akoğlan, M. (2001), 'Türkiye'de Konaklama Sektöründe Çalışan Kadınların Tükenmişlik Durumları Üzerine Bir Araştırma', Turizm Akademik Dergisi, 1(12).

Altındal, Y. (2016), Türkiye'de Turizm Sektöründe Kadın Girişimciliğinin Gelişiminin İncelenmesi: Batı Akdeniz Bölgesi-Güney Ege Bölgesi Karşılaştırması, Doktora Tezi, Süleyman Demirel Üniversitesi, Sosyal Bilimler Enstitüsü, Isparta.

Altındal, Y. ve Gül Sallan, S. (2016), 'Turizm Sektöründe Kadın Girişimcilerin Risk Alma Deneyimleri', Toplum ve Demokrasi, 10(21), ss.115-131.

Anafarta, N., Sarvan, F. ve Yapıcı, N. (2008), 'Konaklama İşletmelerinde Kadın Yöneticilerin Cam Tavan Algısı: Antalya İlinde Bir Araştırma', Akdeniz I.I.B.F. Dergisi, 15, ss.111-137.

Arzjani, Z. ve Rahiminezhad, V. (2011), 'Rural Women and Their Roles in Tourism', International Journal of Bio-Resource \& Stress Management, 2 (1), ss.1-4.

Arlı, E. (2013), 'Deniz Turizm Sektöründe Algılanan Cinsiyet Ayrımcılığı ve Cinsiyet Önyargısı: Karamürsel Meslek Yüksekokulu Öğrencileri Üzerine Bir Araştırma', Çalışma ve Toplum, 2013/3.

Arıca, R. (2014), 'Seyahat İşletmeciliği Literatürünün Gelişim Süreci: Türkiye'de Hazırlanan Lisansüstü Tez Çalışmalarının Bibliyometrik Olarak İncelenmesi', VII. Lisansüstü Turizm Öğrencileri Kongresi, Kuşadası, Aydın, 04-05 Nisan ss: 446462.

Avcı, N. (2018), Turizm Sektöründe Çalışan Kadınların Karşılaştıkları Engeller ve Bu Engellere Yönelik Algıları, Yüksek Lisans Tezi, Muğla Sıtkı Koçman Üniversitesi, Sosyal Bilimler Enstitüsü, Muğla.

Aydın, B. (2017), 'Yükseköğretim Kurulu Tez Merkezinde (YÖKTEZ) Yiyecek İçecek İşletmeciliği Alanında Kayıtlı Bulunan Tezlerin Bibliyometrik Analizi', Journal of Multidisciplinary Academic Tourism, 2 (1), ss.23-38.

Ayaz, N. ve Çobanoğlu, S. (2017), 'Ev Kadınlarının Turizm Amaçlı Yöresel Yemek Üretimine Bakış Açıları: Bartın İli Örneği', Karabük Üniversitesi Sosyal Bilimler Enstitüsü Dergisi, 7(1), ss.413-427.

Aydın, Ş., Özkul, E., Tandoğan Karakaş, G. ve Şahin, N. (2007), 'Otel İşletmelerinde Kadınların Üst ve Tepe Yönetime Yükseltilmesinde Cam Tavan Etkisi Üzerine Bir Araştırma', XV. Ulusal Yönetim ve Organizasyon Kongresi, 25-27 Mayıs 2007, Sakarya.

Bao, J. (2002), 'Tourism Geography As The Subject Of Doctoral Dissertations In China, 1989-2000', Tourism Geographies, 4 (2), ss.148-152.

Başaran, M. ve Ateş, A. (2019), 'Kırsal Kalkınmanın Sağlanmasında Kadın İstihdamı: Afyonkarahisar Gazlıgöl Termal Turizm Bölgesi Araştırması', Journal of YasarUniversity, 14(54), ss.87-95.

Başaran, M. (2019), Kırsal Kalkınma Bölgelerinde Kadın İstihdamı: Afyokarahisar Gazlıgöl Termal Turizm Bölgesi Örneği, Yüksek Lisans Tezi, Selçuk Üniversitesi, Sosyal Bilimler Enstitüsü, Konya.

Bayram Erkol, G. (2018), 'Kadın Girişimciler ve Turizm: Mevcut Durum ve Sorunlar Üzerine Sinop İlinde Bir Araştırma', İşletme Araştırmaları Dergisi, 10(2), ss.56-88.

Bayram Erkol G., Bayram T. A., ve Sürücü Altunöz Ö. (2018), Turizm ve Kadın, Ankara:Detay Yayıncılık.

Bıyıklı, S. (2015), Turizm Sektöründe Kadın İstihdamının Önemi ve Karşılaşılan Sorunlara Yönelik Bir Uygulama, Yüksek Lisans Tezi, Atatürk Üniversitesi, Sosyal Bilimler Enstitüsü, Erzurum.

Boyacıoğlu, Z. E. (2014), 'Kırsal Turizmde Kadın Girişimciliği: Edirne Örneği', Uluslararası Sosyal ve Ekonomik Bilimler Dergisi, 4(2), ss.82-90.

Bozok, D., Kılıç, S.N., ve Özdemir, S.S. (2017), 'Turizm Literatüründe Kırsal Turizmin Bibliyometrik Analizi', Journal of Human Sciences, 14(1), ss.187-202.

Broadus, R. N. (1987), 'TowardA Definition Of "Bibliometrics"', Scientometrics, 12 (5-6), ss.373-379. 
Bustillo, M., Fernández-Macías, E., Antón, J. I. ve Esteve, F. (2011). Measuring more than money: The social economics of job quality, Edward Elgar Publishing, Cheltenham, UK.

Cave, P. ve Kılıç, S. (2010). The Role of Women in Tourism Employment with Special Reference to Antalya, Turkey, Journal of Hospitality Marketing \& Management, 19 (3): 280-292.

Cheng, C., Li, X., Petrick, J. F., ve O'Leary, J. T. (2011), 'An Examination Of Tourism Journal Development', Tourism Management, 32, ss. 53-61.

Ciğer, A. ve Uyar, F. G. (2016), 'Konaklama İşletmelerinde Kadın Muhasebecilerin Cam Tavan Algısına Yönelik Bir Araştırma: Antalya İli Örneği', Manas Sosyal Araştırmalar Dergisi, 5(2), ss.43-58.

Coşar, Y. (2017), 'Somut Olmayan Kültürel Mirasın Korunmasında Kadın Emeğinin Rolü', Sosyal Politika Çalışmaları Dergisi, 17(38), ss.115-138.

Cukier, J. Norris, J. ve Wall G. (1996), 'Thelnvolvement of Women in theTourismlndustry of Bali Indonesia', Journal of Development Studies, 33 (2), ss.248-271.

Çakıcı, C., Yıldırım, O. ve Karacaoğlu, S. (2013), 'Ulusal Turizm Kongreleri Bildirilerinin Bibliyometrik Profili', 14. Ulusal Turizm Kongresi, Kayseri, 05-08 Aralık, ss. 14291447.

Çakır, G. P. Barakazı, ve M. Barakazı, E. (2017), 'Turizm Sektöründe Çalışan Kadınların Karşılaştı̆̆ı Sorunları Değerlendirmeye Yönelik Bir Araştırma', The Journal of Academic Social Science Studies, 61, ss.461-674.

Çamlıbel, Z. (2010), İş Güçlüğü ve İş Değiştirme Niyeti İlişkisi: Konaklama İşletmelerinde Kadın Çalışanlar Üzerine Bir Araştırma, Yüksek Lisans Tezi, Sakarya Üniversitesi, Sosyal Bilimler Enstitüsü, Sakarya.

Çiçen, C. (2019), Turizm Sektöründe Kadın İşgücünün Performansının İncelenmesi: Edirne İli Konaklama İşletmeleri Örneği, Yüksek LisansTezi, Trakya Üniversitesi, Sosyal Bilimler Enstitüsü, Edirne.

Çiçek D. ve Kozak N. (2012), 'Anatolia: Turizm Araştırmaları Dergisi'nde Yayımlanan Hakem Denetimli Makalelerin Bibliyometrik Profili', Türk Kütüphaneciliği, 26, 4, ss.734-756.

Çiçek, D., Zencir, E. ve Kozak, N. (2017), 'Women in Turkish Tourism', Journal of Hospitality and Tourism Management, 31, ss.228-234.

Çelebi, N. (1997), Turizm Sektöründeki Küçük Işyeri Örgütlerinde Kadın Girişimciler, Ankara:T.C. Başbakanlık Kadının Statüsü ve Sorunları GM.

Çelik, M. ve Şahingöz Akar, S. (2018), 'İş Yaşamında Cinsiyet Ayrımcılığı: Kadın Aşçılar Örneği', Journal of Tourism and Gastronomy Studies,6(3), ss. 370-383.

Dalkıranoğlu, T. (2006), Çalışma Yaşamında Kadın İşgücü ve Cinsiyet Ayrımcılığı: Konaklama İşletmelerinde Bir Uygulama, Yüksek Lisans Tezi, Anadolu Üniversitesi, Sosyal Bilimler Enstitüsü, Eskişehir.

Dalkıranoğlu, T. ve Çetinel, G. F. (2008), 'Konaklama İşletmelerinde Kadın ve Erkek Yöneticilerin Cinsiyet Ayrımcılığına Karşı Tutumlarının Karşılaştırılması', Dumlupınar Üniversitesi Sosyal Bilimler Dergisi, 20, ss.277-297.

Demir, M. (2011), 'İş yaşamında ayrımcılık: Turizm sektörü örneği', Uluslararası İnsan Bilimleri Dergisi,8(1), ss.761-784, Erişim: http://www.insanbilimleri.com.

Demirbulat, Ö. G. ve Dinç, N.T. (2017), 'Sürdürülebilir Turizm Konulu Lisansüstü Tezlerin Bibliyometrik Profili', Seyahat ve Otel İşletmeciliği Dergisi,14 (2), ss.2030.

Demirel, H. Z. ve Perçin Şahin, N. (2018), 'Otel İşletmelerindeki Kadın Yöneticilerin Kariyer Engellerinin Kariyer Geliştirme Stratejileri Üzerine Etkisi', Uluslararası Sosyal Araştırmalar Dergisi, 11(57), ss. 546-557.

Demirkol, Ş., Fidan, F. ve Pelit, E. (2004), 'Turizm Sektöründeki Bayan İşgörenlerin Karşılaştıkları Sorunlar ve Otel İşletmelerinde Bir Uygulama', Abant lzzet Baysal Üniversitesi Sosyal Bilimler Enstitüsü Dergisi, 1(8), ss.71-88. 
Demirer, F. S. (2018), Örgüt Kültürü ve Örgütsel Destek Algısının Cam Tavan Engeli ile İlişkisi: İstanbul Turizm Sektörü Kadın Çalışanları Üzerine Bir Araştırma, Yüksek Lisans Tezi, Nişantaşı Üniversitesi, Sosyal Bilimler Enstitüsü, İstanbul.

Diodato, V. P. (1994), 'Dictionary of Bibliometrics', USA: The Hawthorne Press.

Diker, O., Taşpınar, O. ve Soylu, Y. (2017), 'İstanbul/Beyoğlu-Taksim Bölgesindeki 4-5 Yıldızlı Otel Mutfak Personelinin Çelişki Duygulu Cinsiyetçilik Düzeyleri ile Kadın Çalışanlara Yönelik Tutumları İlişkisinin İncelenmesi', Journal of Life Economics, 4(4), ss.125-142.

Dinçer İstanbullu, F., Akova, O., Ertuğral Muğan, S. ve Çifçi Aydoğan, M. (2016), 'Türkiye'de Turizm Sektöründe Kadın İstihdamı: İmkanlar ve Engeller', Eurasian Academy of Sciences Social Sciences Journal, 1, ss.379-395.

El-Sherif İbrahim, N. S., Pritchard, A. ve Jones, E. (2007), '(Un)veilingWomen's Employment in the Egyptian Travel Business', İçinde Pritchard, A., Morgan, N. Ateljevic, I., Harris,C. (edt.) Tourism and Gender: Embodiment, Sensuality and Experience, Wallingford: CABI, 290-301.

Elmas, Ş. (2002), Turizm Sektöründe Ücretli ve Ücretsiz Kadın İşgücü: Kapadokya Bölgesi, Nevşehir-Avanos-Ürgüp, Yüksek lisans Tezi, Orta Doğu Teknik Üniversitesi, Sosyal Bilimler Enstitüsü, Ankara.

Ertaş, Ç. (2018). 'Otellerde Çalışan Erkeklerin Kadınların Çalışmasına Karşı Tutumu: Erilliğin Etkisi', İşletme Araştırmaları Dergisi, 10(4), ss.625-645.

Evren, S. ve Kozak, N. (2012), 'Türkiye'de 2000-2010 Yılları Arasında Yayımlanan Turizm Konulu Makalelerin Bibliyometrik Analizi', VI. Lisansüstü Turizm Öğrencileri Araştırma Kongresi Bildiri Kitabı, ss.250-267, Ankara: Detay Yayıncılık.

Fidan, D. (2015), Yönetimde Cinsiyet Farkları Kariyer Öncelikleri ve İş Koşullarına Duyarlılı: Turizm Sektöründe Bir Uygulama, Yüksek Lisans Tezi, Beykent Üniversitesi, Sosyal Bilimler Enstitüsü, İstanbul.

Fidan, F. ve Nam, D. (2012), Kırsal Turizmde Yeni Dinamikler: Kadın Girişimciler-Taraklı Örneği, KMÜ Sosyal ve Ekonomik Araştırmalar Dergisi, 14(23), ss.51-57.

Gebelek, G. (2008), The New International Migration From a Gender Persfective: Study of Post-Soviet 'Servants of Tourism' in Antalya, Yüksek Lisans Tezi, Koç Üniversitesi, Sosyal Bilimler Enstitüsü, İstanbul.

Ghodsee, K. (2005), The Red Riviera: Gender, Tourism, and Post socialism on the Black Sea, Durham, NC:Duke University Press.

Güçer, E., Keleş, Y., Demirdağ, A.Ş. ve Çelikkanat, N. (2018), 'Kadın İşgörenlerin Karşılaştığı Sorunların Örgütsel Sessizlikleri Üzerindeki Etkisi: Bodrum'daki Otel İşletmelerinde Bir Araştırma', Afyon Kocatepe Üniversitesi Sosyal Bilimler Dergisi, 20(2), ss.1-18.

Gökmen Ekiz, Ç. (2011), 'Türk Turizminin Yabancı Gelinleri: Marmaris Yöresinde Turizm Sektöründe Çalışan Göçmen Kadınlar', Çalışma ve Toplum, 1(28), ss. 201-231.

Güçer, E., Yayla, Ö. ve Koç, B. (2013), 'Konaklama İşletmelerinin Seçiminde Biyolojik Cinsiyete ve Cinsiyet Kimliğine Dayalı Reklam Etkisi', 14. Ulusal Turizm Kongresi, 5-8 Aralık, Kayseri, ss.858-869.

Gül, M. ve Gül, K. (2017), 'Yiyecek-İçecek Sektöründe KOSGEB Kredi Desteğinin Kadın Girişimcilerin Ekonomik Risk Algısına Etkisi', 8. Uluslararası Girişimcilik Kongresi, Balıkesir, ss.583-597.

Gül, M. ve Gül, K. (2018), 'Kırsal Kalkınma ve Kırsal Turizm Konulu Lisansüstü Tezlerin Bibliyometrik Profili', Uluslararası Sosyal ve Ekonomik Bilimler Dergisi ISSN: 2146-0078, 8(2), ss. 56-62.

Güleç, M. (2015), Kadın Çalışanlarda Cam Tavan Sendromunun Örgütsel Vatandaşlığa Etkileri Kuşadası 4 ve 5 Yıldızlı Otel İşletmelerinde Bir Uygulama, Yüksek Lisans Tezi, Adnan Menderes Üniversitesi, Sosyal Bilimler Enstitüsü, Aydın. 
Güler, Y. (2017), Turizm Ürününün Korunmasında Kadınların Rolü: Cittaslow Seferihisar Örneği, Yüksek Lisans Tezi, Atılım Üniversitesi, Sosyal Bilimler Enstitüsü, Ankara.

Güzel, B. (2009), Kadın Çalışanların Kariyer Engellerinin Örgütsel Bağıııı Üzerine Etkisi: Dört ve Beş Yıldızlı Otel İşletmelerinde Bir Uygulama, Doktora Tezi, Dokuz Eylül Üniversitesi, Sosyal Bilimler Enstitüsü, İzmir.

Hall, C. M. (2011), 'Publish And Perish? Bibliometric Analysis Journal Ranking and The Assessment of ResearchQualityin Tourism', Tourism Management, 32, ss. 16-27.

Huang, S. ve Hsu, C.H. C. (2008), 'Recent Tourism and Hospitality Research in China', International Journal of Hospitality \& Tourism Administration, 9 (3), ss. 267-287.

Hussain, A., Fatima, N. ve Kumar, D. (2011), 'Bibliometric Analysis Of The 'Electronic Library' Journal (2000-2010)', Webology, 8(1), ss.1-11.

Işık, C., Tırak, L. ve Işık, Z. (2016), 'Potansiyel Kadın Turizmcilerin Girişimcilik ve İnovasyon Eğilimlerinin Belirlenmesi', İstanbul Arel Üniversitesi Iktisadi-Idari Bilimler Fakültesi Ekonomi, Yönetim ve Sosyal Araştırmalar Dergisi, 1(1), ss. 3144.

Işık, Z., Çetinkaya, N. ve Işık, F.M. (2017), 'Mutluluğun İş Tatmini Üzerindeki Rolü: Erzurum İli Palandöken Kış Turizm Merkezinde Yer Alan Konaklama İşletmelerindeki Kadın Çalışanlar Üzerine Bir Uygulama', Atatürk Üniversitesi Sosyal Bilimler Enstitüsü Dergisi, 21(2), ss.457-471.

Işık, C., Günlü Küçükaltan, E., Kaygalak Çelebi, S, Çalkın, Ö. Enser, İ. ve Çelik, A. (2019), 'Turizm ve Girişimcilik Alanında Yapılmış Çalışmaların Bibliyometrik Analizi', Güncel Turizm Araştırmaları Dergisi, 3(1), ss.119-149.

Jordan, F. (1997), An Occupational Hazard? Sex Segregation in Tourism Employment, Tourism Management 18 (8), ss.525-534.

Jogaratnam, G. McCleary, K. W, Mena, M. M. ve EunYoo, J. J. (2005), 'An Analysis Of Hospitality and Tourism Research: Institutional Contributions', Journal of Hospitality \& Tourism Research, 29 (3), ss.356-371.

Jucan, M. S. ve Jucan, C. N. (2013), Gender Trends in Tourism Destination, Social and Behavioral Sciences, 92, ss.437 - 444.

Kanten, P., Yeşiltaş, M. ve Akdağ, G. (2014), 'Kariyer Engellerinin Mutluluk Üzerindeki Etkisinde Kariyer Motivasyonunun Rolü: Otel İşletmelerinde Kadın İşgörenler Üzerine Bir Uygulama', 15. Ulusal Turizm Kongresi, 13-16 Kasım, Ankara, ss.411430.

Kavak, O. Kaygın, E. (2017), 'Toplumsal Cinsiyet Algısı İle Girişimcilik Eğilimi Arasındaki İlişkinin Turizm Sektörü Açısından İncelenmesi', Iwact'17 International West Asia Congress of Tourism Research, 28 Sept-01Oct, Bildiri Kitabı, Van-Turkey, ss.436450.

Kaya, Ş. (2017), 'Turizm'de Kadın Emeği', Karatahta Iş Yazıları Dergisi, 9, ss.1-22.

Kayabaşı Torun, E. (2017), 'Kırsal Turizmde Kadınların Rolü ve Önemi', Türk ve İslam Dünyası Sosyal Araştırmalar Dergisi, 4(12), ss.252-261.

Kaya, İ. ve Topbaş, F. (2019), 'Turizm Sektöründe Cinsiyete Dayalı Ücret Ayrımcıığı', Izmir Democracy University Social Sciences Journal, 2 (1), ss.74-87.

Karakaş, A. ve Gökmen, G. (2016), 'Turizm Sektöründe Kadın Girişimcilerin Profilinin Incelenmesi', Journal of Recreation and Tourism Research, 3(3), ss.18-25.

Korkmaz, M., Özkök, F. ve Uluocak, Ş. (2019), 'Yerel Halkın Kadın Turistlere Yönelik Bakış Açısının Toplumsal Cinsiyet Rolleri Eşitliği ve Yaşam Değerleri Bağlamında İncelenmesi:Gökçeada Örneği', Journal of Life Economics, 6(1), ss.35-60.

Koutsou, S., Notta, O., Samathrakıs, V. ve Partalıdou, M. (2009), 'Women's Entrepreneurship and Rural Tourism in Greece: Private Enterprises and Cooperatives', South European Societyand Politics, 14, ss.191-209.

Kozak, N. (1994), 'Anatolia: Turizm Araştırmaları Dergisi'nde Yayımlanan Yazılar Üzerine Bir İnceleme', Anatolia: Turizm Araştırmaları Dergisi, 5 (Aralık), ss.22-33. 
Kozak, N. (1995), 'Türkiye'de Yayımlanan Turizm Konulu Makaleler Üzerine Bir İnceleme', Anatolia: Turizm Araştırmaları Dergisi, 6 (1), ss.62-72.

Kozak, N. (2000), 'Türkiye'de Akademik Turizm Literatürünün Gelişim Süreci Üzerine Bir Inceleme', DAÜ: Turizm Araştırmaları Dergisi, 1(1), ss.15-55.

Kozan, G.Y., Özdemir, S. S. ve Günlü, E. (2014), 'Turizm Yazınında Deniz Turizminin Olgusal Gelişimi', Dokuz Eylül Üniversitesi Denizcilik Fakültesi Dergisi, 6(2), ss.115-129.

Köse, Z. (2014), Turizmde Kadın İstihdamı ve Kadın Girişimciliği: Beypazarı Örneği, Yüksek Lisans Tezi, Hacettepe Üniversitesi, Sosyal Bilimler Enstitüsü, İstanbul.

Mayuk, A. (2013), Çalışma Yaşamında Kadın ve Konaklama İşletmelerinde Kadın Yöneticilerde Cam Tavan Sendromunu Önlemeye Yönelik Stratejiler: İstanbul Örneği, Yüksek Lisans Tezi, Balıkesir Üniversitesi, Sosyal Bilimler Enstitüsü, Balıkesir.

McKercher, Law, R. ve Lam, T. (2006), 'Rating Tourism And Hospitality Journals', Tourism Management, 27, ss.1235-1252.

Neziroğlu, S. (2018), Toplumsal Cinsiyet Bağlamında Turizm Haberleri Üzerine Bir İnceleme, Yüksek Lisans Tezi, Akdeniz Üniversitesi, Sosyal Bilimler Enstitüsü, Antalya.

Oktik, N. (2001), 'Turizm Sektöründe Çalışan Kadınların Toplumsal Değişime Etkileri', Sosyal ve Beşeri Bilimler Araştırma Dergisi, 4.

Öktem, Ş., Kubat, G. ve Kızıltan, B. (2018), 'Otel İşletmelerinde Kadın İşgören Davranışlarını Etkileyen Algılara İlişkin Bir Araştırma', Anatolia: Turizm Araştırmaları Dergisi, 29(2), ss.197-208.

Özel, Ç. H. ve Kozak, N. (2012), 'Turizm Pazarlaması Alanındaki Makalelerin Bibliyometrik Profili (2000-2011) ve Bradford Yasası', VI. Lisansüstü Turizm Öğrencileri Araştırma Kongresi Bildiri Kitabı, ss.423-433. Ankara: Detay Yayıncılık.

Özmen, K., Bilgin, Ö.E. ve Ubbelohde, G. (2018), 'Otel İşletmelerinde Kadın Yönetici Olmak: Sakarya İli Örneği', 1. Uluslararası Turizmde Yeni Jenerasyonlar ve Yeni Trendler Konferansı, 01-03 Kasım, Sapanca, ss.145-161.

Özgüven, E. (2017), Kadının Çalışmasına Yönelik Tutumda ve Sosyal Kaytarma Davranışında Dindarlık Düzeyinin Etkisi: Otel Çalışanlarına Yönelik Bir Araştırma, Yüksek Lisans Tezi, Batman Üniversitesi, Sosyal Bilimler Enstitüsü, Batman.

Palmer, A. L., Sese, A. ve Montano, J.J. (2005), 'Tourism and Statistics: Bibliometric Study 1998-2002, Annals of Tourism Research, 32 (1), ss.167-178.

Pelit, E., Güçer, E. ve Demirdağ, A. Ş. (2016), 'Kadın İş Görenlerin Karşılaştığı Sorunların İ̧ Bırakma Eğilimlerine Etkisi: Otel İşletmelerinde Bir Araştırma', Mehmet Akif Ersoy Üniversitesi Sosyal Bilimler Enstitüsü Dergisi, 8(15), ss.43-65.

Pritchard, A. (1969), 'Statistical Bibliography or Bibliometrics?', Journal of Documentation, 25, ss.348-349.

Pritchard, A. (2014), The Wiley Blackwell Companion to Tourism, "Gender and Feminist Perspectives in Tourism Research" Cahpter 25, Edited by Alan A. Lew, C. Michael Hall, and Allan M. Williams, First Edition, John Wiley \& Sons,

Ryan, C. (2005), 'The Ranking and Rating of Academics and Journals inTourism Research', Tourism Management, 26, ss.657-662.

Savgın, C. E. ve Göktürk Bostan, T. (2017), 'Kırsal Alanlarda Kadın Girişimcilerin Sorunlarının İncelenmesi: Yiyecek İçecek Sektörüne Yönelik Bir Araştırma', 8. Uluslararası Girişimcilik Kongresi, Balıkesir, ss.1092-1107.

Serinikli, N. (2019), 'Kırsal Alandaki Mikro Kadın Girişimcilerin Kooperatifleşmeye Karşı Tutumları: Agro-Turizm Kadın Kooperatifleri', Girişimcilik Ve Kalkınma Dergisi, 14(1), ss.45-57. 
Sezen, B. (2008), Örgütlerde Kadın Çalışanların Karşılaştıkları Cam Tavan Engeli: Orta ve Büyük Ölçekli Otel İşletmelerinde Bir Araştırma, Yüksek Lisans Tezi, Çanakkale Onsekiz Mart Üniversitesi, Sosyal Bilimler Enstitüsü, Çanakkale.

Singh, N. Hu, C. ve Roehl, W.S. (2007), 'Text Mining A Decade Of Progress İn Hospitality Human Resource Management Research: Identifying Emerging Thematic Development, International Journal of Hospitality Management, 26, ss.131-147.

Sökmen, A. ve Şahingöz Akar, S. (2017), 'Kadın Çalışanlarda Cam Tavan Yansıtıcılarından Kurum İkliminin, Tatmini ve İşten Ayrılma Niyetine Etkisi: Otel İşletmelerinde Bir Araştırma', İşletme Araştırma Dergisi, 9(1), ss.113-133.

Sürücü Altunöz, Ö., Kargiglioğlu, Ş. ve Ak, S. (2017), 'Kırsal Turizmde Geleneksel Kültürün Yansıtılması ve Kadın İstihdamı: Beypazarı Örneği', I. International Sustainable Tourism Congress, November 23-25, ss.550-565.

Şahin, S. ve Acun, A. (2015), 'Turist Rehberliği Alanının Bibliyometrik Profili (Ulusal Turizm Kongreleri Bildirileri)', Balıkesir Üniversitesi Sosyal Bilimler Enstitüsü Dergisi, 18 (34), ss.213-234.

Şahin, B., Sönmez, B., Kazoğlu, H. İ. ve Saygı, C. A. (2014), 'Kadın İşgörenlerde Algılanan Kariyer Engelleri ve Kariyer Sonlandırma Eğilimi İlişkisi: Konaklama İşletmelerinde Bir Araştırma', 15. Ulusal Turizm Kongresi, 13-16 Kasım, Ankara, ss.445-461.

Şahin, E., Akdağ, G., Çakıcı, C. ve Onur, N. (2018), 'Gastronomi ve Mutfak Sanatları Anabilim Dallarında Yayınlanan Tezlerin Bibliyometrik Analizi', Güncel Turizm Araştırmaları Dergisi, 2 (1), ss.30-41.

Şimşek, Ş. M., Özgener, Ş. veillhan, İ. ( 2017), 'Turizm Sektöründeki Kadın Girişimciler ve Yöneticiler Açısından Otantik Liderliğin Sosyal Tembellik Üzerindeki Etkileri: Yaşam Tatmininin Düzenleyici Rolü', Seyahat ve Otel İşletmeciliği Dergisi, 14(3), ss.88-109.

Temizkan, P. Çiçek, D. ve Özdemir, C. (2015), Sağlık Turizmi Konusunda Yayınlanan Makalelerin Bibliyometrik Profili, International Journal of Human Sciences, 12 (2), ss.394-415.

TOBB Turizm Sektör Meclisi, (2016), Turizm Raporu 2016, (Erişim 24.07.2019).

Tosun, C., Bilim, Y., Cihangir, S. İ., Gökçe, F. ve Kocabozdoğan, K. (2011), 'Bölgesel Kalkınmada AB Destekli Turizm Eğitim Projeleri: Turizm Sektöründe Kadın İstihdamını Geliştirme Projesi (TUSKIP)', 1. Uluslararası Turizm ve Otelcilik Sempozyumu, 29 Eylül-1 Ekim .

Tosun, C., Gökçe, F., Bilim, Y., Kocabozdoğan, K., Çalkın, Ç. ve Babat, D. (2011), 'AB Destekli Turizm Eğitim Projeleri Samandağ Turizm Sektöründe Kadın İstihdamını Geliştirme Projesi SAKIP', I.Uluslararası IV.Ulusal Eğirdir Turizm Sempozyumu, 1-4 Aralık, Eğirdir, Isparta, ss.651-660.

Tuncel, I. (2009), Turizm Haberlerinde Yabancı Uyruklu Kadınların Temsili, Yüksek Lisans Tezi, Selçuk Üniversitesi, Sosyal Bilimler Enstitüsü, Konya.

Tuncel, I. (2011), 'Turizmin Cinsiyeti Ya Da Kadın Gölgesinde Turizm', Gümüşhane Üniversitesi Iletişim Fakültesi Elektronik Dergisi, 2, ss.140-164.

Tunçsiper, B., Özkan, Ç. ve Boz, M. (2017), 'Kırsal Turizm ve Kadın Girişimciler: Nusratı Köyü Örneği', 8. Uluslararası Girişimcilik Kongresi, Balıkesir, ss.77-85.

TÜíK (2019), İşgücü İstatistikleri Haber Bülteni, Sayı: 30688, http://www.tuik.gov.tr/PreHaberBultenleri.do?id=30688.

Tükeltürk Aydın, Ş. ve Perçin Şahin, N. (2008), 'Turizm Sektöründe Kadın Çalışanların Karşılaştıkları Kariyer Engelleri ve Cam Tavan Sendromu: Cam Tavanı Kırmaya Yönelik Stratejiler', Yönetim Bilimleri Dergisi, 6(2), ss.113-128.

Tümen, C. B. (2009), Turizm Sektöründe Kadın İstihdamının Özellikleri ve Karşılaşılan Sorunlar, Yüksek Lisans Tezi, Mersin Üniversitesi Sosyal Bilimler Enstitüsü, Mersin. 
Türker, N. (1997), 'Konaklama İşletmelerinde Cinsel Taciz ve Cinsiyet Ayrımı', Anatolia: Turizm Araştırmaları Dergisi, 8(2), ss. 74-76.

Türktarhan, G. ve Kozak, N. (2012), 'Turizm Yılığı'nın Bibliyometrik Profili. VI. Lisansüstü Turizm Öğrencileri Araştırma Kongresi Bildiri Kitabı, ss.567-584, Ankara: Detay Yayıncılık.

Uçar, N. (2012), 'Kırsal Alanda Turizmle Modernleşen Kadın', Uluslararası Sosyal ve Ekonomik Bilimler Dergisi, 2(2), ss.111-115.

UNDP Human Development Report, (2010), UNESCO Education for All Global Monitoring Report.

UNWTO (2019), Gobal Report on Women and Tourism, Second Edition, https://www.eunwto.org/doi/pdf/10.18111/9789284420384.

Uğuz Çelik, S. ve Topbaş, F. (2014), 'Toplumsal Cinsiyet ve Kadın Emeği: Turizm Sektörüne Betimsel Bir Yaklaşım', Akademik Sosyal Araştırmalar Dergisi, 2(7), ss.487-509.

Uğuz Çelik, S. ve Topbaş, F. (2016), 'Turizmde Kadın İstihdamı ve Ücret Ayrımcılığı: Karşılaştırmalı Bir Analiz', Anatolia: Turizm Araştırmaları Dergisi, 27(1), ss.62-78.

Ülkü, A., Erol, G. ve Köroğlu, A. (2013), 'Kadın Tüketicilerin Turistik Ürün Satın Alma Davranışlarını Etkileyen Faktörler', 14. Ulusal Turizm Kongresi, 5-8 Aralık, Kayseri, ss.839-857.

Ülkü, A. ve Köroğlu, A. (2014), 'Kadın Tüketicilerin Turistik Ürün Satın Alma Davranışlarını Etkileyen Faktörler', Journal of Recreation and Tourism Research, 1(3), ss.1-11.

Ünlüönen K. ve Şahin S. Z.(2011), 'Turizmde İstihdam', Elektronik Sosyal Bilimler Dergisi, 10(37), ss.1-25.

Women First (2010), The Case for Change: WomenWorking in Hospitality, Leisure, Travel and Tourism, Women1st _ Case _ For _ Change _ Executive _ Summary November2010.

Yalçın, H. (2010), 'Millî Folklor Dergisi'nin Bibliyometrik Profili (2007-2009)', Millî Folklor, 22(85), ss.205-211.

Yılmaz, G. (2017), 'Ulusal Turizm Kongrelerinde Gastronomi ve Mutfak Sanatları Alanı İle İlgili Yayınlanan Bildiriler Üzerine Bir Araştırma', Turizm ve Araştırma Dergisi, 6 (1), ss.24-39.

Yirik, Ş. ve Yıldırım Ilgaz, B. (2014), 'Turizm Sektöründeki Kadın Girişimcilerin Bireysel Değerlerinin Demografik Özellikleri Açısından İncelenmesi: Antalya İli Örneği', Mustafa Kemal Üniversitesi Sosyal Bilimler Enstitüsü Dergisi, 11(26), ss.361-378.

Yirik, Ş. ve Yıldırım Ilgaz, B. (2014), 'Turizm Sektöründeki Kadın Girişimcilerin Bireysel Değerlerille Risk ve Belirsizlik Algıları Arasındaki İlişkilerin Alan Araştırması İle İncelenmesi: Antalya Örneği', Niğde Üniversitesi IiBF Dergisi, 7(2), ss.97-111.

Yüncü Karadeniz, D. ve Kozak, N. (2012), 'Anatolia Turizm Araştırmaları Dergisi'nin Bibliyometrik Analizi: Araştırma Konuları ve Kurumlar Arası İşbirliğinin Sosyal Ağ Analiz İle İncelenmesi', VI. Lisansüstü Turizm Öğrencileri Araştırma Kongresi Bildiri Kitabı, ss.642-661, Ankara: Detay Yayıncılık.

Zencir, E. ve Kozak, N. (2012), 'Sosyal Bilimler Enstitü Dergileri'nde Yayımlanan Turizm Makalelerinin Bibliyometrik Profili (2000-2010)', VI. Lisansüstü Turizm Öğrencileri Araştırma Kongresi Bildiri Kitabı, ss.673-685, Ankara: Detay Yayıncılık. 